\title{
Flexural Behavior of Double-Skin Steel Tube Beams Filled with Fiber-Reinforced Cementitious Composite and Strengthened with CFRP Sheets
}

\author{
Ahmed Al-Nini ${ }^{1}$, Ehsan Nikbakht ${ }^{1}$, Agusril Syamsir ${ }^{2,3, * \mathbb{C}, \text { Nasir Shafiq }}{ }^{1, * \mathbb{C}}$, \\ Bashar S. Mohammed ${ }^{1}{ }^{\mathbb{D}}$, Amin Al-Fakih ${ }^{1, *}{ }^{\mathbb{D}}$, Waleed Al-Nini ${ }^{4,5}$ and Y. H. Mugahed Amran ${ }^{6,7}$ \\ 1 Civil and Environmental Engineering Department, Universiti Teknologi Petronas, \\ Bandar Seri Iskandar 32610, Malaysia; ahmed_17005180@utp.edu.my (A.A.-N.); \\ ehsan.nikbakht@utp.edu.my (E.N.); bashar.mohammed@utp.edu.my (B.S.M.) \\ 2 Institute of Energy Infrastructure (IEI), Universiti Tenaga Nasional, Kajang 43000, Malaysia \\ Department of Civil Engineering, Universiti Tenaga Nasional, Kajang 43000, Malaysia \\ Almarja for Engineering and Cosultancies, 30th Street, Bait Bouse, Sana'a 452, Yemen; alnini.eng@gmail.com \\ Faculty of Engineering, Thamar University, Dhamar 87246, Yemen \\ 6 Department of Civil Engineering, College of Engineering, Prince Sattam Bin Abdulaziz \\ University, Alkharj 11942, Saudi Arabia; m.amran@psau.edu.sa \\ 7 Department of Civil Engineering, Faculty of Engineering and IT, Amran University, Amran 9677, Yemen \\ * Correspondence: agusril@uniten.edu.my (A.S.); nasirshafiq@utp.edu.my (N.S.); \\ amin.ali_g03663@utp.edu.my (A.A.-F.)
}

Received: 25 May 2020; Accepted: 19 June 2020; Published: 9 July 2020

\begin{abstract}
The concrete-filled double skin steel tube (CFDST) is a more viable option compared to a concrete-filled steel tube (CFST) due to consisting a hollow section, while degradation is enhanced simply by using carbon fiber-reinforced polymer (CFRP). Hence, the stabilization of a concrete's ductile strength needs high- performance fiber-reinforced cementitious conmposite. This study investigates the behavior of high-performance fiber-reinforced cementitious composite-filled double-skin steel tube (HPCFDST) beams strengthened longitudinally with various layers, lengths, and configurtion of CFRP sheets. The findings showed that, with increased CFRP layers, the moment capacity and flexural stiffness values of the retrofitted HPCFDST beams have significantly improved. For an instant, the moment capacity of HPCFDST beams improved by approximately $28.5 \%$ and $32.6 \%$ when they were wrapped partially along $100 \%$ with two and three layers, respectively, compared to the control beam. Moreover, the moment capacity of the HPCFDST beam using two partial layers of CFRP along $75 \%$ of its sufficient length was closed to the findings of the beam with two full CFRP layers. For energy absorption, the results showed a vast disparity. Only the two layers with a $100 \%$ full length and partial wrapping showed increasing performance over the control. Furthermore, the typical failure mode of HPCFDST beams was observed to be local buckling at the top surface near the point of loading and CFRP rapture at the bottom of effect length.
\end{abstract}

Keywords: HPCFDST beam; CFRP sheet; flexural stiffness; energy absorption; failure mode; moment capacity

\section{Introduction}

Concrete-filled steel tubes (CFST) are known as structural composite members, wherein the voids of steel tubes are filled with concrete to enhance stiffness and load-bearing capacity [1]. The inter-boundary stresses of structural members are key to engineering advanced composites. Thus, the inherent engineering properties of such materials have earned them the global application as a state-of-the-art 
technique in the construction industry $[2,3]$. In such a design pattern, structural members are combined, such as the case in concrete-filled steel tubes, to provide unprecedented structural properties as solutions to a focused situation [1]. Concrete-filled steel tubes have numerous benefits, several advantages over ordinary structural steel, and normal reinforced concrete applications. The infill of concrete is restrained by the steel tube, resulting in producing a tri-axial limit state of compression that upsurges, which causes a hike in the strain and strength capacities of the infill of concrete [4]. The concrete restrains the steel tubes from both global and local buckling. Consequently, the distortion capacity of a CFST compares favorably with those of hollow tubes [5]. Further, the composited strength of both the concrete and steel offers outstanding compressive axial load and stiffness capacity. This makes the composite highly suitable for compressive structural applications, such as in columns [6]. Concrete-filled steel tubes is also permitted a fast construction since the steel tube abolishes the formwork and reinforcement related to concrete infill and reinforced concrete construction, which is quickly filled and formed [1]. The constituents of HPC contribute most efficiently to different structural requirements including strength, toughness, energy absorption capacity, durability, corrosion resistance, and damage tolerance when subjected to large deformations in structural members [7].

It is reported that, in cases of long-span structural members that require restriction in cross-sectional dimensions and that experience seismic forces, quivers, and vibrations, for such a situation, structural steel-filled concrete offers the best solution [8]. It combines the advantages of the concrete and steel such as the optimized cross-sectional dimensions, high strength, stability, and toughness [3,9]. The flexural behaviors of these concrete-filled steel tube (CFST) composite beams have been increasingly researched by engineers in the last two decades to enable the common use of (CFST) in structural projects [10]. Usually, aside from the fact that the beams, when compared to their hollow steel tube counterpart beams, display a high self-weight in return, they exhibit specific strengths, such as higher ductility, moment capacity, and stiffness. Concrete filled into the tube may significantly reduce or protect local buckling which happens mostly in the hollow tubes' compressed zones [11]. Strengthening is, however, needed in the CFST flexural members because of deterioration due to the natural and environmental factors and possible upgrade of a structural member to accommodate additional loads [12]. Project funding, often times, are significantly raised as a result of the strengthening practices for the present steel and composite structural parts by replacement and addition of new steel elements, because these repair works are time and capital intensive [13]. In recent years, engineers have made utilization of carbon fiber-reinforced polymer (CFRP) schemes for steel sections' strengthening [12-14]. These schemes are suitable for resisting harsh weathers and possess high strength and elasticity compared with its weight ratio higher than those of the steel [15].

The use of CFRP in steel members has been investigated in previous studies. The adoption of different retrofitting techniques, application of loads, and behavioral cohesiveness across the CFRP and steel boundary of composited elements have equally been critically analyzed [6]. Generally, the strengthening of CFST flexural members with CFRP sheets of one direction using the full strengthening sheet of their cross-section has been examined previously in various studies [5]. Carbon fiber-reinforced polymer (CFRP) sheets that can effectively resist the high-tension stress are utilized to mainly upgrade the capacities of both the simply wrapped steel and concrete-steel I-beams when equally laid along their tension flange [16]. In addition, it could be difficult to achieve an adequately strengthened cross-section by reducing the quantity of the CFRP in a partially retrofitted CFST beam. This is so because loads are applied on the top flanges of beams, typically, when used as girders for bridges [17]. Employing the CFRP schemes could thus be considered as an appropriate solution when following the same strengthening concept of steel-beam as the simply supported CFST beams are strengthened from the bottom flanges [18]. Another composite construction innovation is known as the concrete-filled double-skin steel tubes (CFDST). Although the CFDST members display almost all the strengths of the traditional CFST members, they exhibit a lighter in weight, higher bending stiffness, and better cyclic performance [19]. Two concentric steel tubes with concrete sandwiched within them are what embedded in this innovative composite construction. The steel 
tubes can be circular hollow sections (CHS), square hollow sections (SHS), or rectangular hollow sections (RHS) [20] which eventually lead to several possible combinations as shown in Figure 1.

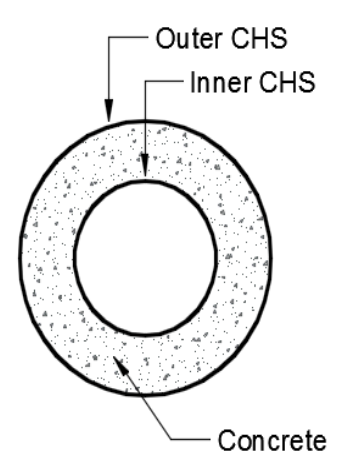

(a)

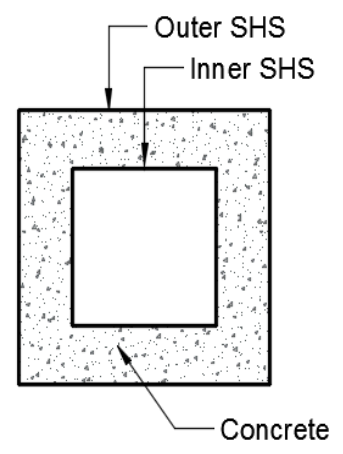

(b)

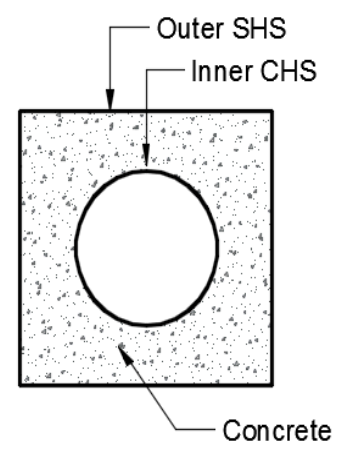

(c)

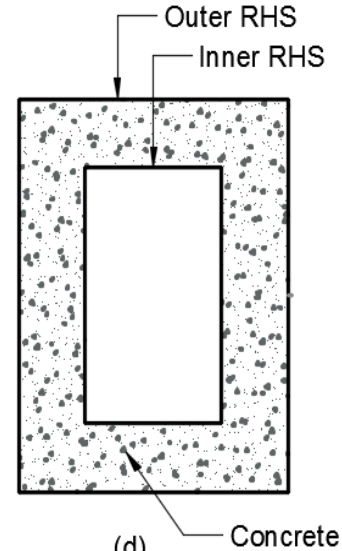

(d)

Figure 1. Cross-sections of double skin steel tube [20] (a) Circular hollow section (CHS) inner and outer, (b) Squre hollow section (SHS) inner and outer, (c) Circular hollow section (CHS) inner and squre hollow section (SHS) outer), and (d) Rectangular hollow sections (RHS) inner and outer.

Yu et al. [21] have studied the flexural behavior of hybrid FRP concrete steel double-skin tubular beam (DSTB). The specimens exhibited high ductility performance and high shear resistance. The authors concluded that the flexural response of a DSTB, including the flexural stiffness, the ultimate load, and cracking can be substantially improved by shifting the inner steel tube toward the tension region or providing FRP bars as additional longitudinal reinforcement. Uenaka and Kitoh [22] have investigated the mechanical behavior of a concrete-filled double skin circular (CFDST) hollow beam. The results presented that the failure mechanisms of the tested beams were governed by the parameter di/do (diameter of inner tube over a diameter of the outer tube) where the beams with highest di/do, experienced filled concrete crushing in the early stage of loading. Moreover, Idris and Ozbakkloglu [23] have studied the effects of varying the inner diameter of steel tube and the use of mechanical connectors on the steel tube on the flexural behavior of hybrid circular double-skin tubular beams under static load. The results showed high inelastic deformation and minimal strength degradations. The higher inner diameter decreased the slip between the concrete and the steel tube of DSTB as well as the mechanical connectors. Therefore, the flexural capacity of the tested beams was improved significantly. Concrete-filled, double-skin steel tube (CFDST) beams using CFRP sheets and high-performance fiber-reinforced cementitious composite have never been investigated to date. This research, therefore, aims to study the effectiveness of employing the unidirectional CFRP sheets in the strengthening of the high-strength rectangular double-skin steel tube beams filled with high-performance reinforced fiber composite concrete under four-point bending. The effects of various parameters, such as configuration, multiple CFRP layers, and varied wrapping lengths of CFRP in high-performance fiber-reinforced cementitious filled-double skin steel tube (HPCFDST) beams, were investigated.

Previous laboratory works have been studied the bending performance of CFST [16-24]. The major findings provided an overview of the CFST bending behavior; nevertheless, the investigational campaigns were limited, and, consequently, it is tough to examine the full-scale specimens to determine significant parameters of the design aspect [17]. Further empirical studies and analytical finite element methods (FEM) would buffer and complement the previous findings. The analytical FEM would offer a great opportunity to investigate parameters such as sizes, geometry, and structural arrangements that are difficult to replicate in actual experimental exercises [18]. Several studies have engaged macro-element and fiber-based models to analyze the CFST column and beam [25]. The use of fiber-reinforced polymer (FRP) composites in the fabrication of novel high-performance composite 
elements, such as beams and columns, in the shape of CFSTs, has been widely become common and tested under flexural loads [26,27].

As proceedings from past studies on CFSTs, a novel composite design of steel tubes with embedded CFRP tubes filled with concrete has gained prominent research interest [1]. The double-skin tubular columns and beams (i.e., DSTCs and DSTBs) depend on a similar CFRP tube confinement apparatus that is shown in CFSTs. In that case, the integration of the benefits of the three essential materials can be harnessed to display good structural performance. Several laboratory investigations have been considered on the composite components $[1,18,27-30]$. However, there are some gaps in the existing studies, which include the compatibility of infilled concrete with the skin section materials. In most cases, concrete was much weaker than the skin sections, therefore either the failure happened in concrete, whereas the skin sections were stressed at moderate to a low level, which would be an uneconomical solution. Therefore, this study used high-strength fiber-reinforced concrete to optimize the load-carrying capacity of the steel section and infilled concrete.

The main findings of these investigations were the the performance features provided by the CFST composites subjected to different loading conditions. Whereas, the most significant role of such design systems is its efficacy in result verifications. For the DSTC and DSTB application, the composite behavioral features between concrete infill and double-skin steel tube filled with ultra-high cementitious materials integrated with CFRP sheets are yet to be studied. Thus, the aim of this study was to experimentally investigate the flexural behavior of a double-skin steel tube filled with high-performance concrete and strengthened with CFRP sheets and to compare the results with an analytical study using equations presented by four different codes.

\section{Materials and Method}

\subsection{Material Characteristic}

Two different cross-sections of rectangular hollow steel tubes were utilized to fabricate the test specimens. The steel properties were given by the supplier as shown in Table 1. Three types of mix design, as shown in Table 2, were proposed with and without the addition of steel fiber to achieve high compressive strength. The water-to-binder ratio was selected to maintain the same workability (slump flow) of all mixes; therefore, it was adjusted accordingly. The fresh properties were determined and tested elsewhere by Nikbakht et al. [31]. The mix design was utilized as a filled mix in the double-skin steel tube beam specimens. The CFRP sheets of SikaWrap- 231C were utilized as strengthening the material. Sikadur-330 was utilized as an adhesive (epoxy) material to attach the CFRP sheets with the steel tubes and the duplicated sheets together. This adhesive material is a mix of two parts of resin (A) and hardener (B) at a ratio of 4:1 by weight. The properties of CFRP and epoxy are shown in Table 3 as given by the manufacturer.

Table 1. Hollow steel tube properties.

\begin{tabular}{ccccc}
\hline Cross-Section $(\mathbf{m m})$ & Tube Location & Yield Strength, fy, (MPa) & Ultimate Strength, fc, (MPa) & Elongation $(\mathbf{m m})$ \\
\hline $75 \times 100 \times 2.30$ & Outer & 385 & 483 & 30 \\
$35 \times 65 \times 2.30$ & Inner & 401 & 421 & 30 \\
\hline
\end{tabular}


Table 2. Trial mix of high-performance composite concrete.

\begin{tabular}{cccc}
\hline Ingredient $\mathbf{( k g} / \mathbf{m}^{\mathbf{3}} \mathbf{)}$ & Mixture A & Mixture B & Mixture C \\
\hline Portland Cement & 600 & 600 & 600 \\
Fly Ash & 390 & 450 & 390 \\
Silica Fume & 78.75 & 78.75 & 78.75 \\
Water & 194.25 & 194.25 & 194.25 \\
River Sand & 480 & 480 & 480 \\
Superplasticizer & 45.15 & 45.15 & 45.15 \\
Steel Fiber & - & - & 21.37 \\
Quartz Sand & 154.35 & 154.35 & 154.35 \\
Water-Binder Ratio & 0.18 & 0.17 & 0.18 \\
\hline
\end{tabular}

Ordinary Portland cement, type-1, was obtained from Lafarge, Malaysia; its specific gravity was 3.5 and conforming to the ASTM C150. Fly ash satisfying ASTM C618 specifications was acquired from a coal fire power station in Manjung, Malaysia. Mean particle size (D50), of fly ash, was determined as 24 microns, and for silica fume, it was 0.16 microns. The BET surface area of fly ash was determined as $0.994 \mathrm{~m}^{2} / \mathrm{g}$, and loose bulk density of fly ash was $860 \mathrm{~kg} / \mathrm{m}^{3}$. Well-graded coarse aggregate was used with size variation from $4.75 \mathrm{~mm}$ to $20 \mathrm{~mm}$ and fineness modulus 7.23. The water absorption and specific gravity for coarse aggregate were $0.44 \%$ and $2.5 \%$, respectively. River sand was used as a fine aggregate with fineness modulus 2.2, water absorption of $1 \%$, and specific gravity 2.55 . Superplasticizer Sika Viscocrete 2044 confirming the specifications of ASTM C494 was used with drinkable water. Copper coated $20 \mathrm{~mm}$ long was used, and $0.3 \mathrm{~mm}$ in diameter and $25 \mathrm{~mm}$ length steel fibers with 2300 MPa were used [32].

Table 3. Carbon fiber-reinforced polymer (CFRP) and adhesive properties [33].

\begin{tabular}{ccccc}
\hline Item & Thickness (mm) & $\begin{array}{c}\text { Maximum Tensile } \\
\text { Strength (MPa) }\end{array}$ & Maximum Strain (\%) & Elastic Modulus (GPa) \\
\hline CFRP & 0.13 & 4900 & 2.1 & 230 \\
Epoxy (nominal) & 2 & 30 & 0.9 & 4.5 \\
\hline
\end{tabular}

\subsection{Test Specimens}

Steel tube beams were utilized with a cross-section established at $75 \mathrm{~mm}$ in width, $100 \mathrm{~mm}$ in height, and $1500 \mathrm{~mm}$ long for the outer steel measurement and $38 \mathrm{~mm}$ in width, $65 \mathrm{~mm}$ in height, and $1500 \mathrm{~mm}$ long for the inner steel measurement. The steel tube thickness was $2.3 \mathrm{~mm}$. However, both steel tubes consolidated to deliver double-skin steel tube beams. Figure 2 demonstrates the cross-section of CFDST.

Eight rectangular specimens of high-performance fiber-reinforced cementitious filled double-skin steel tube (HPCFDST) beams were subjected to four-point bending flexural load. The strengthening of the beams was done by attaching the CFRP schemes along the lower half of the member's cross-sections, which recognized as the partial-unilateral CFRP strengthening scheme; the other type of strengthening was the fully wrapping kind. Details of the labeling beams are shown in Figure 3 and presented in Table 4. B refers to the cross-sections of the beams, while the control specimens' sample is C. The partial wrapping in one direction is represented by the numbers and letter P100, P75, and P50 which have their reputation as a "U-shaped" scheme $(\mathrm{P})$ applied along with a varying percentage of the beams' effective lengths (Le): $100 \%, 75 \%$, and 50\%, respectively. The total number of CFRP layers are represented by the last number and letter (for instance, $3 \mathrm{~L}=$ three layers). The full lengths of three rectangular beams were fully strengthened with the use of different CFRP layers parallel to the beam such as (B-F100-2L); it is known as the "full" scheme (F). Partial wrapping was used for the other six beams with varying lengths and layers. The full and partial-unilateral wrapping scheme, represented by the effective length of specimens, which were $1300 \mathrm{~mm}$ from support to support, moreover, the depth to thickness (D/t) ratios was 43. 


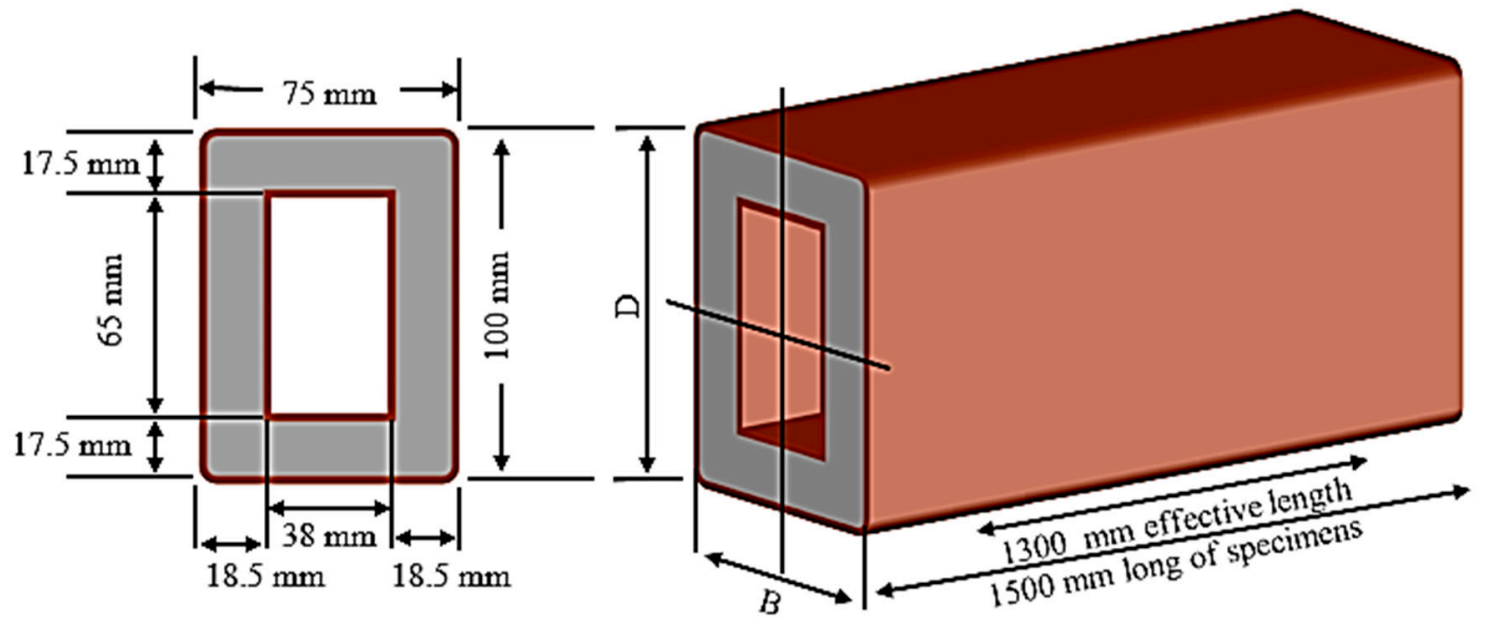

Figure 2. High-performance fiber-reinforced cementitious filled double-skin steel tube (HPCFDST) beamcross-section.
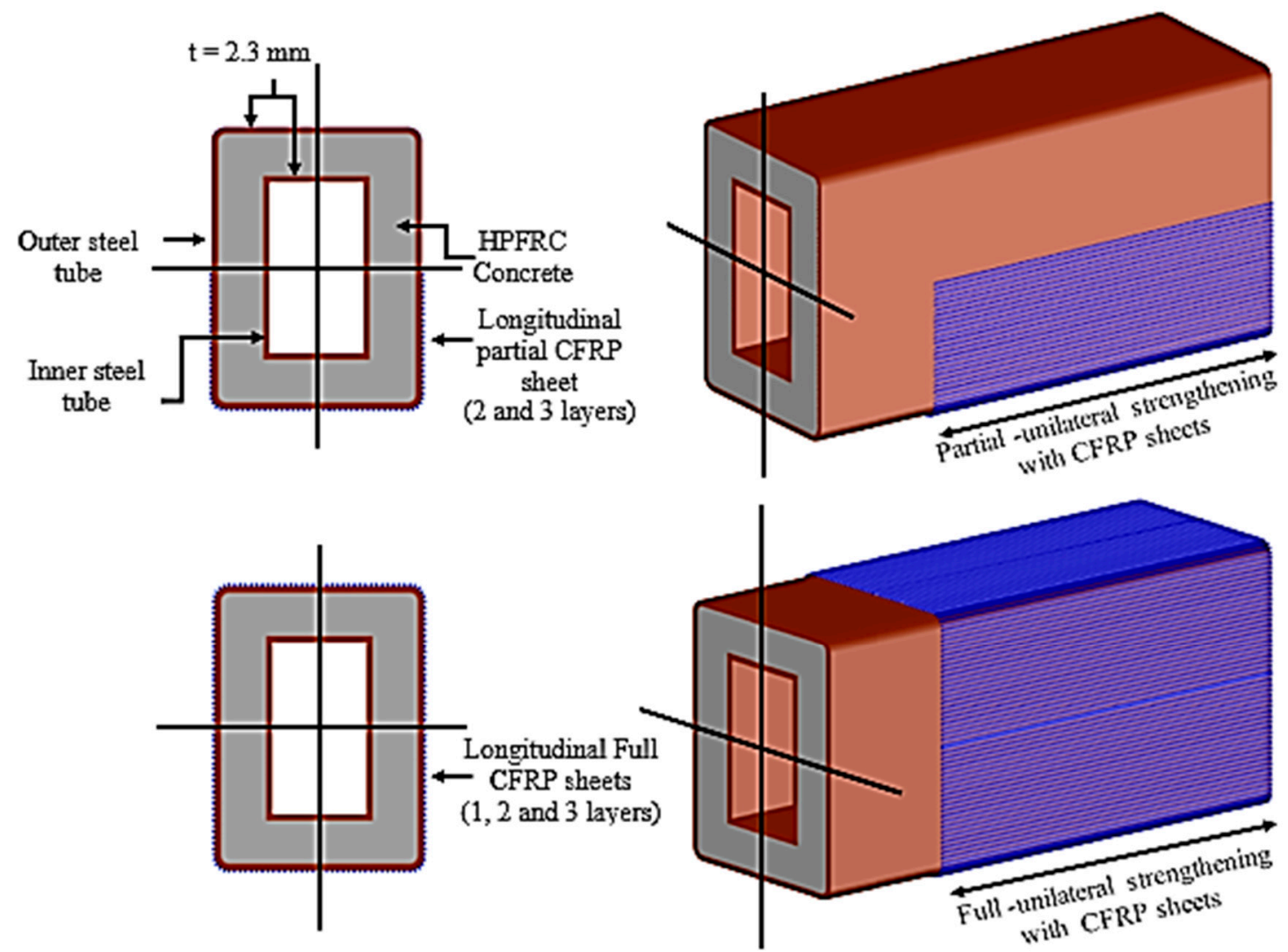

Figure 3. CFRP wrapping sheets: (a) partial wrapping scheme for HPCFDST beams, (b) full wrapping scheme for HPCFDST beams. 
Table 4. Labeling of HPCFDST beams strengthening with CFRP sheets.

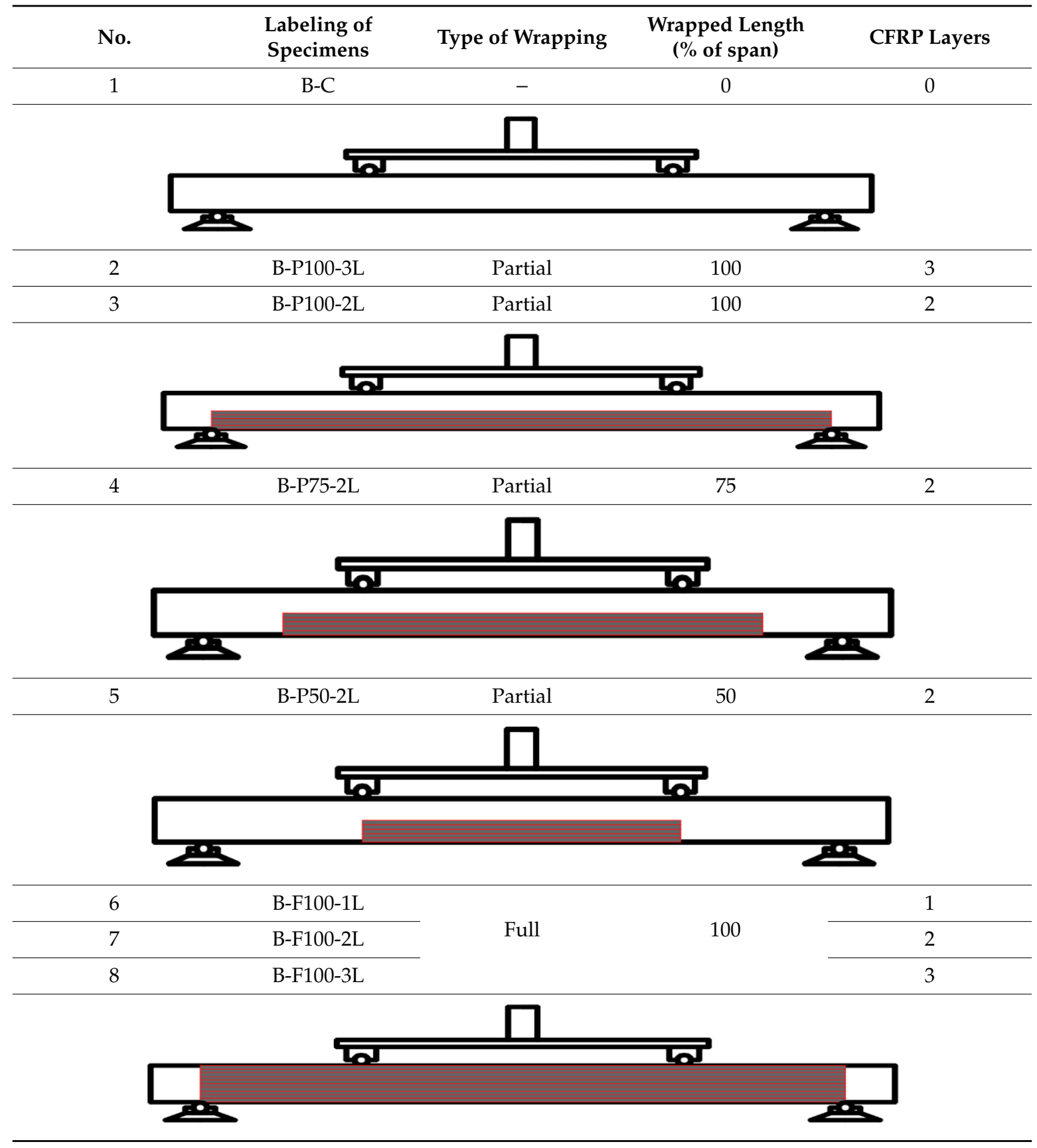

\subsection{Preparation of Specimens}

Prior to beam specimens test, for each mix, three cubes of $100 \times 100 \times 100 \mathrm{~mm}$ were cast and tested under compression at 7, 14, and 28 days following the procedures of ASTM C39-12 [34]. The average compressive strength was reported, and the optimal mix was then chosen to cast the beam specimens.

The electrical saw machine was used to cut all steel tube beams to $1500 \mathrm{~mm}$ by the supplier, as shown in Figure 4a. Afterward, double skin steel tubes fabrication was done on all specimens in the workshop by welding small steel tube cross-section inside the big steel tube beams. A low-speed electrical grinder was then utilized with sandpaper (24 grit) to roughen the pre-marked zone only from the carbon layer, this was also to ensure that there was no rust, paint and other undesirable material on the outside of the steel tube and as a result of grinding these tubes with this type and size of sandpaper, the roughness of the surface increased, and it interlocked the CFRP with the surface of the steel tube 
beam as shown in Figure 4b. Acetone liquid was used to clear the surface of the steel of the grinding dust and dirt. This is illustrated in Figure 4c. Aside from the fact that the surface of the steel tube was clean, the adhesive material, Sikadur-303, (epoxy) was mixed according to the manufacturer's instructions by $4: 1$, and the sticky materials were applied into the steel tube surface immediately as shown in Figure $4 \mathrm{~d}$. Then, simultaneously and in a way that is parallel to the beam's direction, the first and second layer of CFRP was attached instantly around the steel tube beams, respectively. The air void between the CFRP and steel tube beam was removed by a unique ribbed roller to ensure that the thickness of the adhesive material was uniformly distributed along the effective length of the beam, as shown in Figure 4e. The specimen was cured under room temperature, and all specimens were cover by a roller-plastic to keep it clean from concrete casting. Next, the steel tube beam was set upstanding and supported by G-clamp for the more effortless casting of the HPC inside the beam. A silicon pad was glued to the bottom part of the steel tube beam, which temporarily secured it to avoid water leak during the process of placing the HPC as shown in Figure 4f. One concrete batch was used to cast two beams according to the cross-section type and concrete mixer capacities as shown in Figure $4 \mathrm{~g}$. In continuation, the end of strain gauges was soldered with wire before being positioned in the proper location after marking it with a pen, as shown in Figure $4 \mathrm{~h}$. A strain gauge resistance of 120 $\Omega$ was attached and glued using Araldite and 3-second glue as shown in Figure 4i. Once the sample was ready, the beam stayed placed in its correct position inside the UTM machine as in Figure $4 \mathrm{~h}$. The strain gauge was then tested with a multi-meter to make sure it has not broken before the test. After that, the load was applied at the rate of $0.5 \mathrm{kN} / \mathrm{min}$ on the beam, and the specimen was deflected until a maximum force of $450 \mathrm{kN}$ was reached, and at this point, a rupture occurred in the outer surface of the test specimen. 


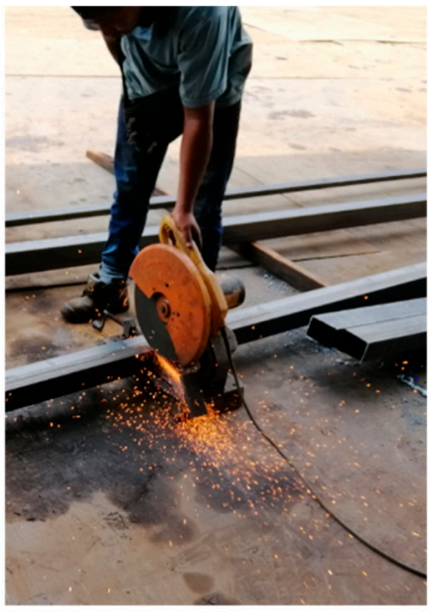

a)

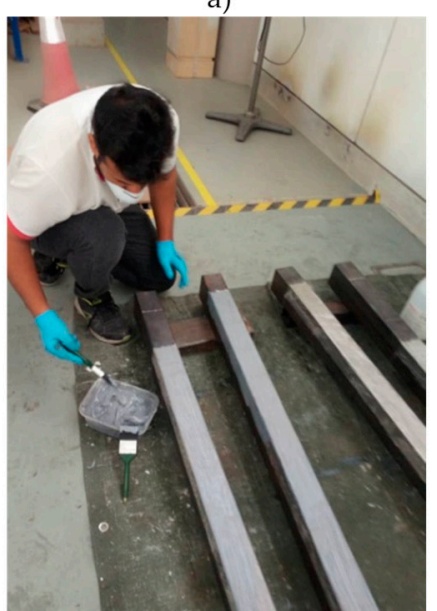

d)

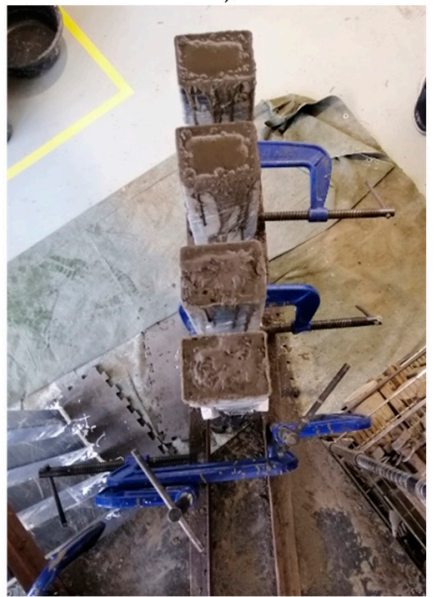

g)

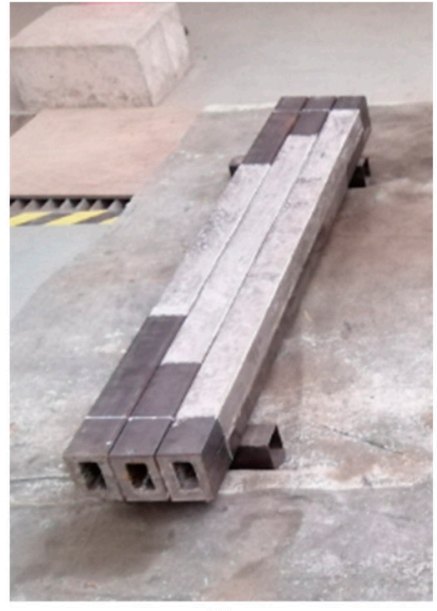

b)

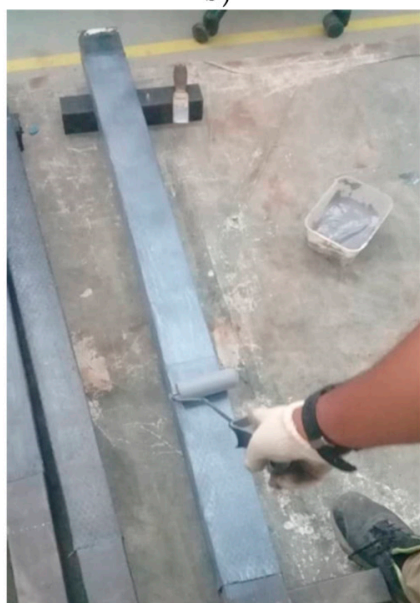

e)

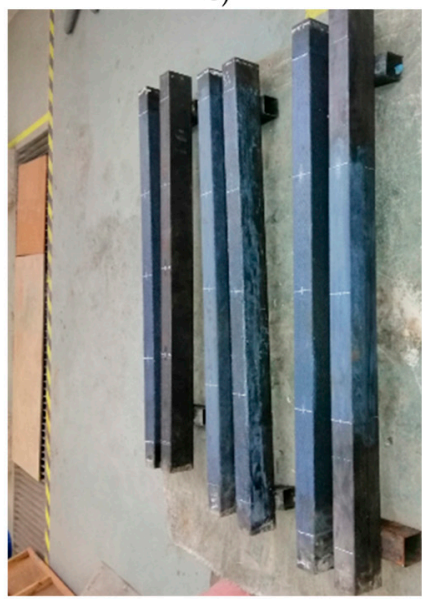

h)

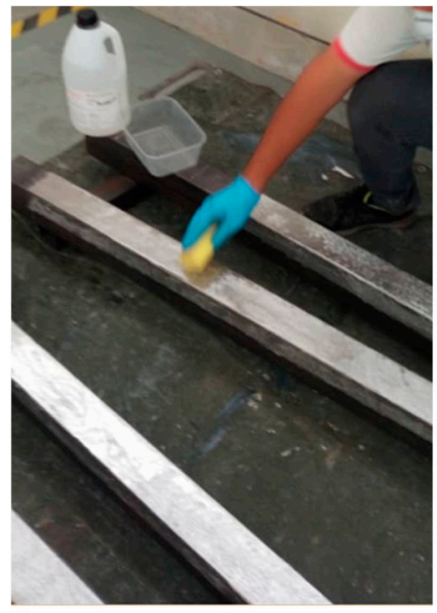

c)

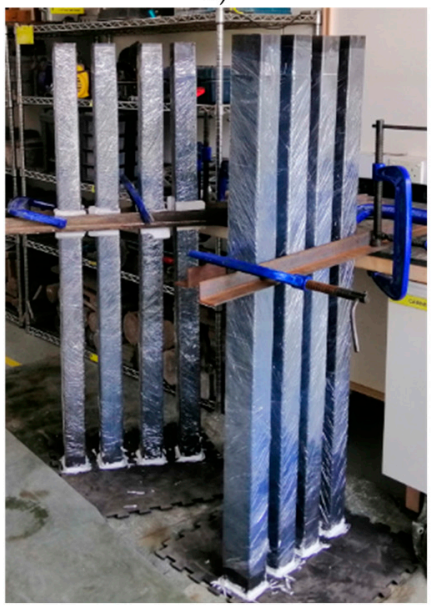

f)

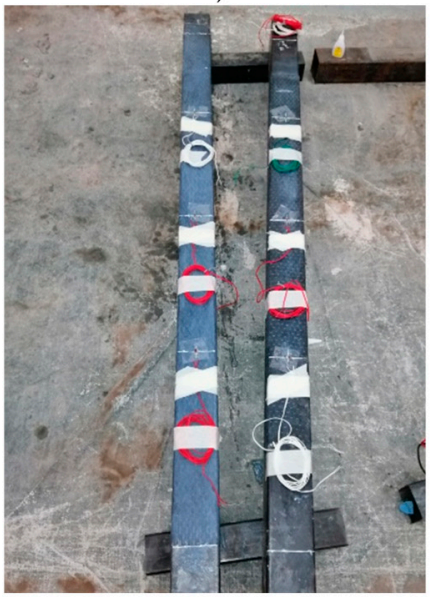

i)

Figure 4. (a) Cutting and Fabrication of beams; (b) grinding of beams; (c) cleaning of beams by acetone; (d) applying of epoxy; (e) attaching CFRP; (f) Setting-up of beams; (g) casting concrete; (h) marking place of stain gauges; (i) attaching strain gauges.

\subsection{Instrumentations and Testing Setup}

The composite beams (infilled concrete in double-skin steel tubes) were designed to behave as a flexural member. Therefore to predict the failure mechanism, the test setup was designed so that the maximum stress should be induced within the middle-third span. Hence, the strain gauges were 
installed in such a manner that the dominating mode of strain could be identified via testing, and data could be used for flexural analysis.

The four-point bending tests were utilized in this study to locate the maximum load capacity of HPCFDST beams. A dynamic machine with a limit capacity of $500 \mathrm{kN}$ was used. Three LVDTs were utilized to measure the displacement. The strain gauge was used to study the tensile stress at a different location of the beam. The positioning of the LVDT is based on the critical area of deflection. More so, it was at the bottom of the beam because the maximum deflection is expected to be at the bottom and center of the beam. A total of four strain gauges was utilized in the investigations. One strain gauge was situated on the top of the beam and the other three at the bottom of the beam, as shown in Figure 5 .

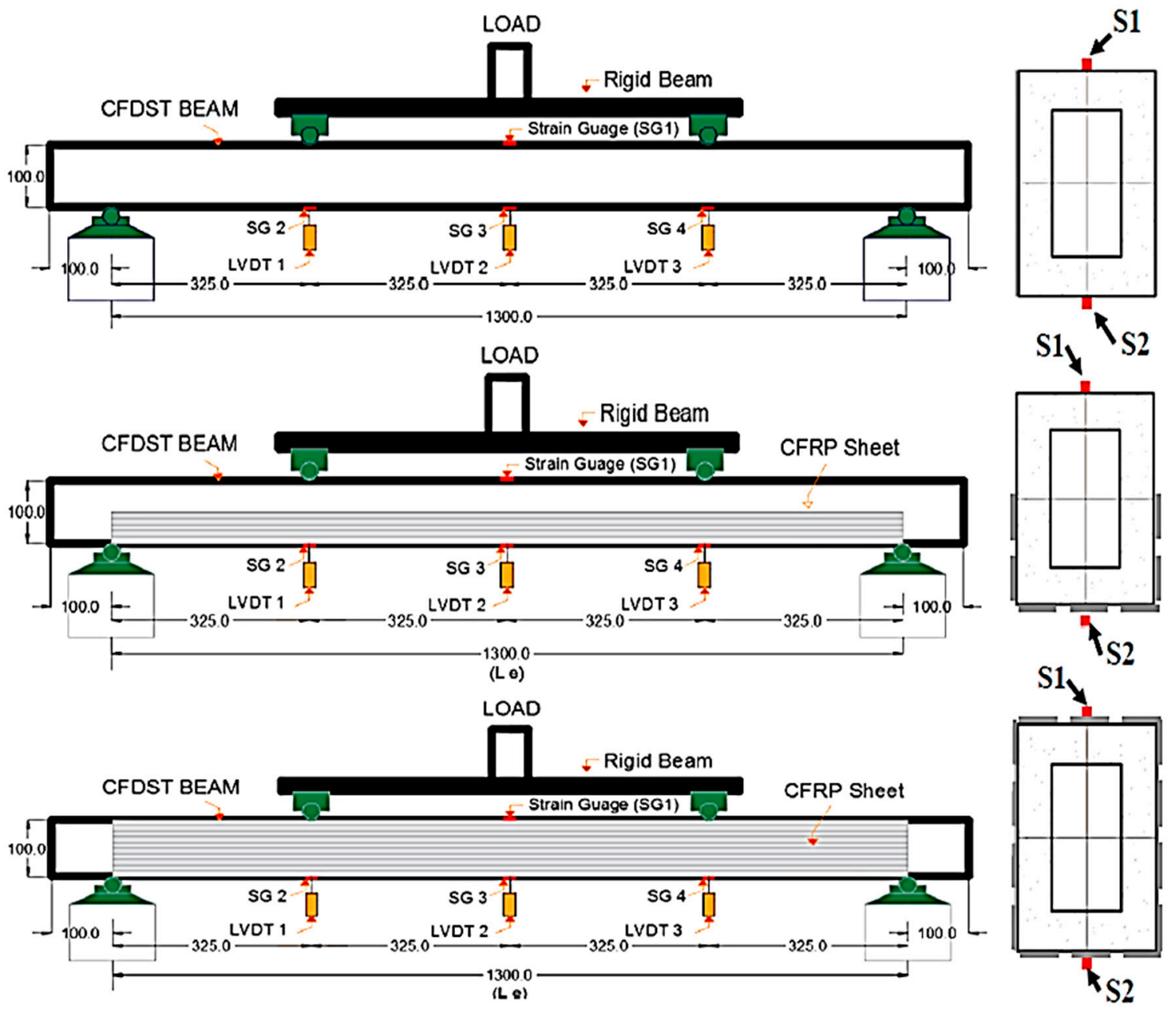

Figure 5. Setup of the test of HPCFDST beams strengthening with CFRP scheme (all units in mm).

\section{Test Results and Discussion}

\subsection{Compressive Strength of HPFRCC}

The concrete mix design was built to help to achieve a compressive strength. The compressive strength of the trial mixtures results is shown in Figure 6. The average result of the compression strength of the concrete cubes for Mix A, B, and C at 28 days is 92.96, 103.89, and $108.03 \mathrm{MPa}$, respectively. Mix $C$ shows higher compressive strength due to the presence of steel fiber. Thus, mix $C$ was used to cast the beams throughout the test. 


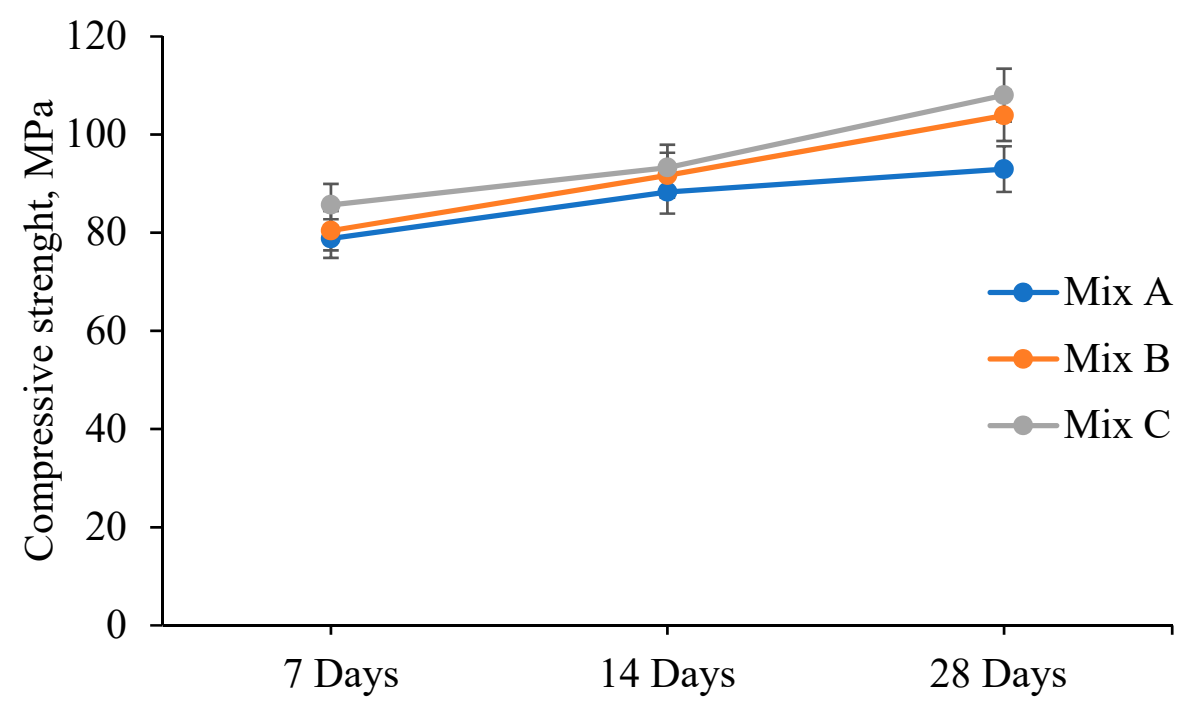

Figure 6. Trial mix of the compressive strength results.

\subsection{Results of HPCFDDST Beam}

\subsubsection{Moment Carrying Capacity}

All Strengthening specimens' ultimate moment capacity $\left(\mathrm{M}_{\mathrm{ue}}\right)$ either ruptured or delaminated when the limit of their CFRP sheets was reached. The $\mathrm{M}_{\mathrm{ue}}$ ratio reached by the retrofitted sample to the maximum control sample capacity was used to calculate the load improvement ratio (LIR). The LIR has been determined based on the control sample (B-C) capacity for the HPCFDS samples strengthened with CFRP. Table 5 shows the sample values of $\mathrm{M}_{\mathrm{ue}}$ and LIR, while in Figure 7 is a comparison of the values of $\mathrm{M}_{\mathrm{ue}}$ for the tested HPCFDST samples. Achieving an LIR of about 1.35, the moment capacity of the sample with the fully retrofitting sheets (B-F100-3L) was found to be $32.7 \mathrm{kN} \cdot \mathrm{m}$; this was the highest of the LIR values with full and partial specimen schemes. Generally, the increase in the moment capacity of the strengthening HPCFDST beams was as a result of a rise in the number of layers of the CFRP. The moment, Mu value of the B-P100-2L sample (2 CFRP layers) was $31.1 \mathrm{kN} \cdot \mathrm{m}$, which later improved to $32.1 \mathrm{kN} \cdot \mathrm{m}$ as a result of using three CFRP layers (B-P100-3L) an LIR of 1.33 was thus achieved. The sample's capacity of (B-P75-2L) was raised to $+25 \%$ more than the control samples' average capacity because of using two layers of CFRP along $75 \%$ of its effective length which was extremely close to the result obtained for the B-F100-2L specimen $(+26 \%)$ as in either specimen, no CFRP delamination failure occurred. Once they reached their maximum tensile strength, the CFRP for both samples ruptured from the bottom mid-span zone. Meanwhile, the HPCFDST beam's capacity could not be enhanced by the $50 \%$ strengthened length due to the earlier CFRP delamination failure. However, due to the fact that the CFRP schemes were positioned along the half-length of the beams and the bonding strength between the CFRP and steel tube in this zone was lower than the peeling stress, the roughness of the steel structure was not sufficient to prevent the failure of the delamination; this finding is in line with other studies [29]. The effect of the roughness of the steel surface also corresponded to the findings of previous studies, although not very significant in this case, and the studies in focus concluded that the roughness of the surface of steel and the characteristics of the adhesive (epoxy) material would determine to increase the mechanical bond interaction as the strength of the bonding between the two adherent parts can improve by increasing the roughness of the steel surface [33]. 
Table 5. HPCFDST beams results.

\begin{tabular}{|c|c|c|c|c|c|c|c|}
\hline Number & $\begin{array}{l}\text { Specimen's } \\
\text { Designation }\end{array}$ & $\mathbf{M}_{\mathrm{ue}} \mathrm{kN} \cdot \mathrm{m}$ & LIR & $\begin{array}{c}\mathrm{EA} \\
\mathrm{kN} \cdot \mathrm{mm}\end{array}$ & $\mathrm{K}_{\mathrm{ie}} \mathrm{kN} \cdot \mathrm{m}^{2}$ & $\mathrm{~K}_{\mathrm{se}} \mathrm{kN} \cdot \mathrm{m}^{2}$ & Method of Failure \\
\hline 1 & C-B & 24.2 & - & 7912.8 & 711.9 & 491.8 & $\begin{array}{l}\text { An outward buckling (local) at the steel tube's } \\
\text { top surface close to the points of loading. }\end{array}$ \\
\hline 2 & B-P100-3L & 32.1 & 1.33 & 7021.4 & 910.6 & 699.7 & \multirow{3}{*}{$\begin{array}{l}\text { An outward buckling (local) at the steel tube's } \\
\text { top surface (one-sided failure). }\end{array}$} \\
\hline 3 & B-P100-2L & 31.1 & 1.29 & 8076.3 & 838.3 & 643.0 & \\
\hline 4 & B-P75-2L & 30.2 & 1.25 & 7179.1 & 845.4 & 651.9 & \\
\hline 5 & B-P50-2L & 24.2 & - & 5431.1 & 765.9 & 569.2 & \multirow{2}{*}{$\begin{array}{l}\text { An outward buckling (local) at the steel tube's } \\
\text { top surface close to the points of loading. }\end{array}$} \\
\hline 6 & B-F100-3L & 32.7 & 1.35 & 7722.3 & 986.9 & 734.5 & \\
\hline 7 & B-F100-2L & 30.7 & 1.26 & 8396.1 & 898.9 & 686.8 & $\begin{array}{l}\text { An outward buckling (local) at the steel tube's } \\
\text { top surface (one-sided failure). }\end{array}$ \\
\hline 8 & B-F100-1L & 26.9 & 1.11 & 5416.3 & 796.4 & 600.1 & $\begin{array}{l}\text { An outward buckling (local) at the steel tube's } \\
\text { top surface close to the points of loading. }\end{array}$ \\
\hline
\end{tabular}

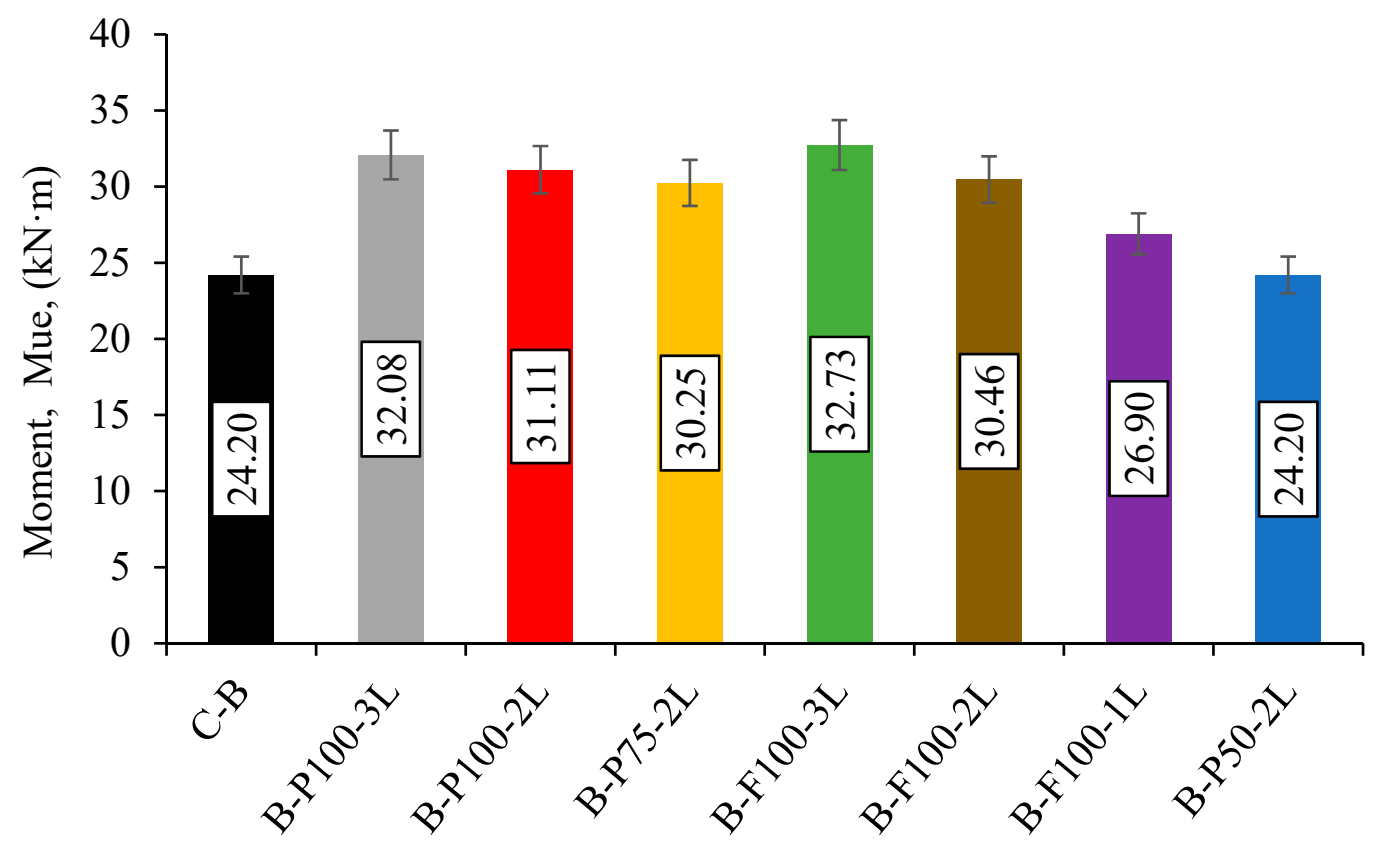

Figure 7. Ultimate moment capacity $\left(\mathrm{M}_{\mathrm{ue}}\right)$ of beams.

\subsubsection{Relationship of Moment-Curvature Responses}

Figure 8 shows the relationship of moment-curvature of HPCFDST beams laminated with the CFRP sheets. The beams displayed the elastic behavior at the beginning of load application until a curvature $(1 / \mathrm{m})$ of approximately 0.1 was reached. Afterward, the moment-curvature relationship showed a plateau in the graph, which indicates an inelastic behavior of the beams. The laminated samples behaved inelastically when the CFRP sheets started delaminated or ruptured. Figure 8a showed the relationship of moment-curvature of the reference beam (B-C), and the beams partially and fully laminated using two layers of CFRP sheets. The beams laminated to $100 \%$, and $75 \%$ of span length (B-P100-2L, B-F100-2L, B-P75-2L) showed about 30\% enhancement in the maximum moment in comparison with the reference beam whereas the beam laminated to $50 \%$ of the span length (B-P50-2l) achieved almost the similar value of the maximum moment. Figure $8 \mathrm{~b}$ shows the relationship of moment-curvature of the reference beam and the fully and partially wrapped beams to $100 \%$ span length using one layer (B-F100-1L) and three layers of CFRP sheets (B-P100-3L and B-F100-3L). It is observed that the beams wrapped with three layers of CFRP achieved about $40 \%$ higher ultimate moment than the control beam B-C, whereas the fully wrapped beam laminated to full-span length using one layer of CFRP sheet showed and enhancement in the maximum moment of about $10 \%$. By comparing the effects of full wrapping and partial wrapping of the beams, it was not notice any significant improvement in the maximum moment capacity. It was observed that lamination to $50 \%$ span length caused a considerable reduction in the maximum moment capacity of the beams as 
compared to lamination to $75 \%$ and $100 \%$ of the span length. From these results, it can be concluded that the partially wrapped beam using two layers of CFRP sheets and laminated to $75 \%$ span length (B-P75-2L) is considered as the optimum design that carried 30\% higher moment than the reference beam (B-C) and achieved an ultimate curvature $(1 / \mathrm{m})$ of 0.32 .

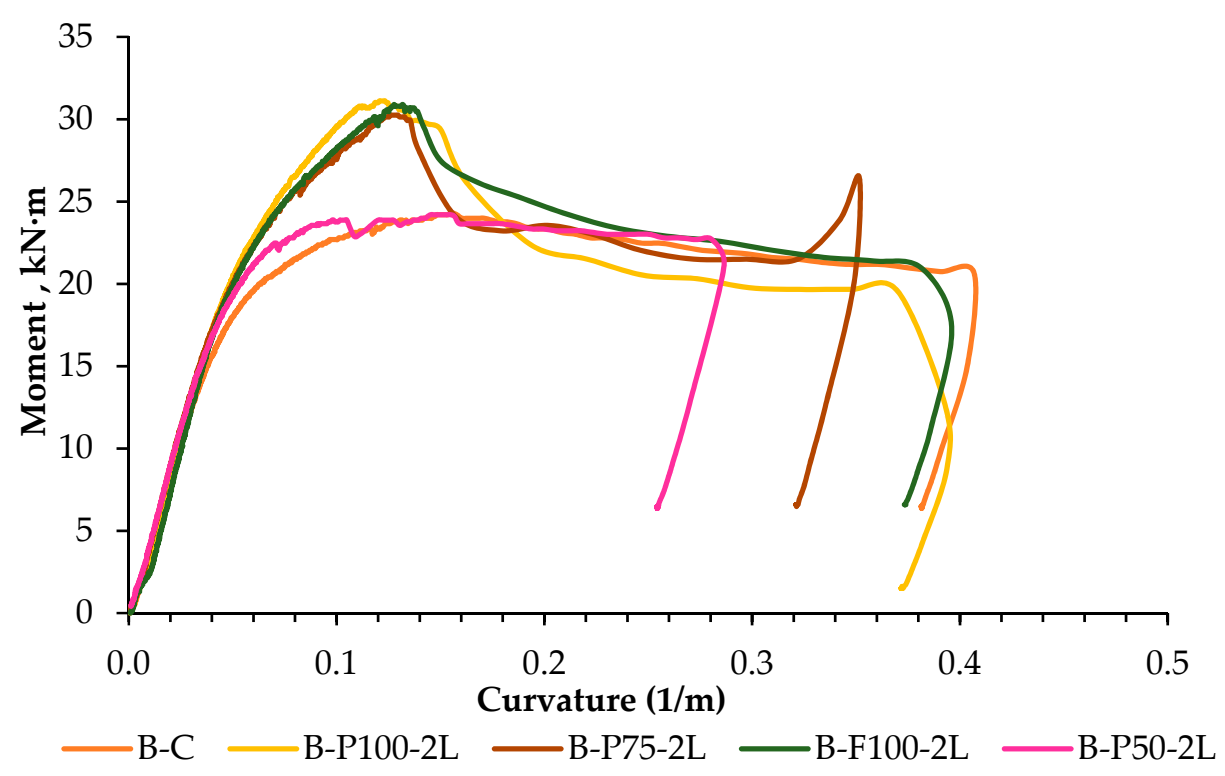

(a)

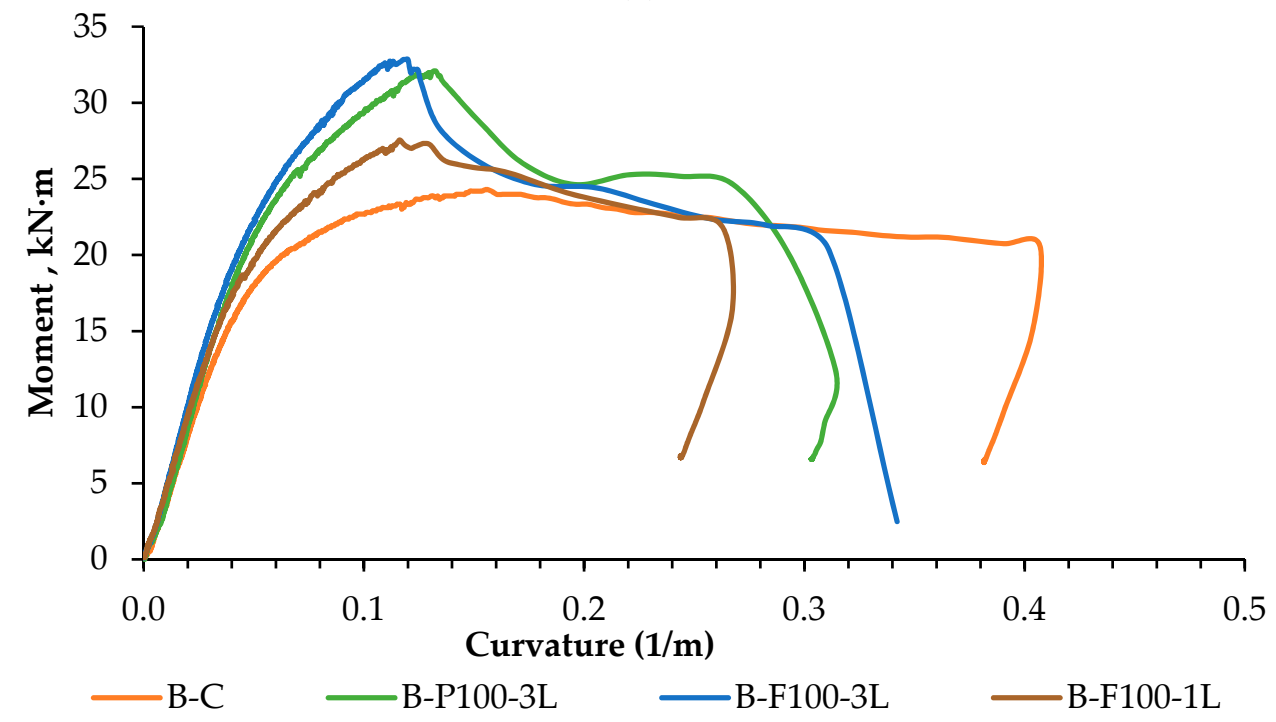

(b)

Figure 8. 8 relationship of HPCFDST beams (a) control beam, partial, and full strengthening with 2 layers of CFRP, and (b) control beam, partial (3 layers), and fully strengthening (1 and 3 layers) with various CFRP layers.

The relationships between moment versus strain for the control specimen (B-C) and (B-P75-2L) is shown in Figure 9, the tensile strain on the tension zone of the simply supported beams augmented progressively along the half-span to the support point, as detected by electrical-strain gauges SG4 and SG2 as shown in Figure 9a. 

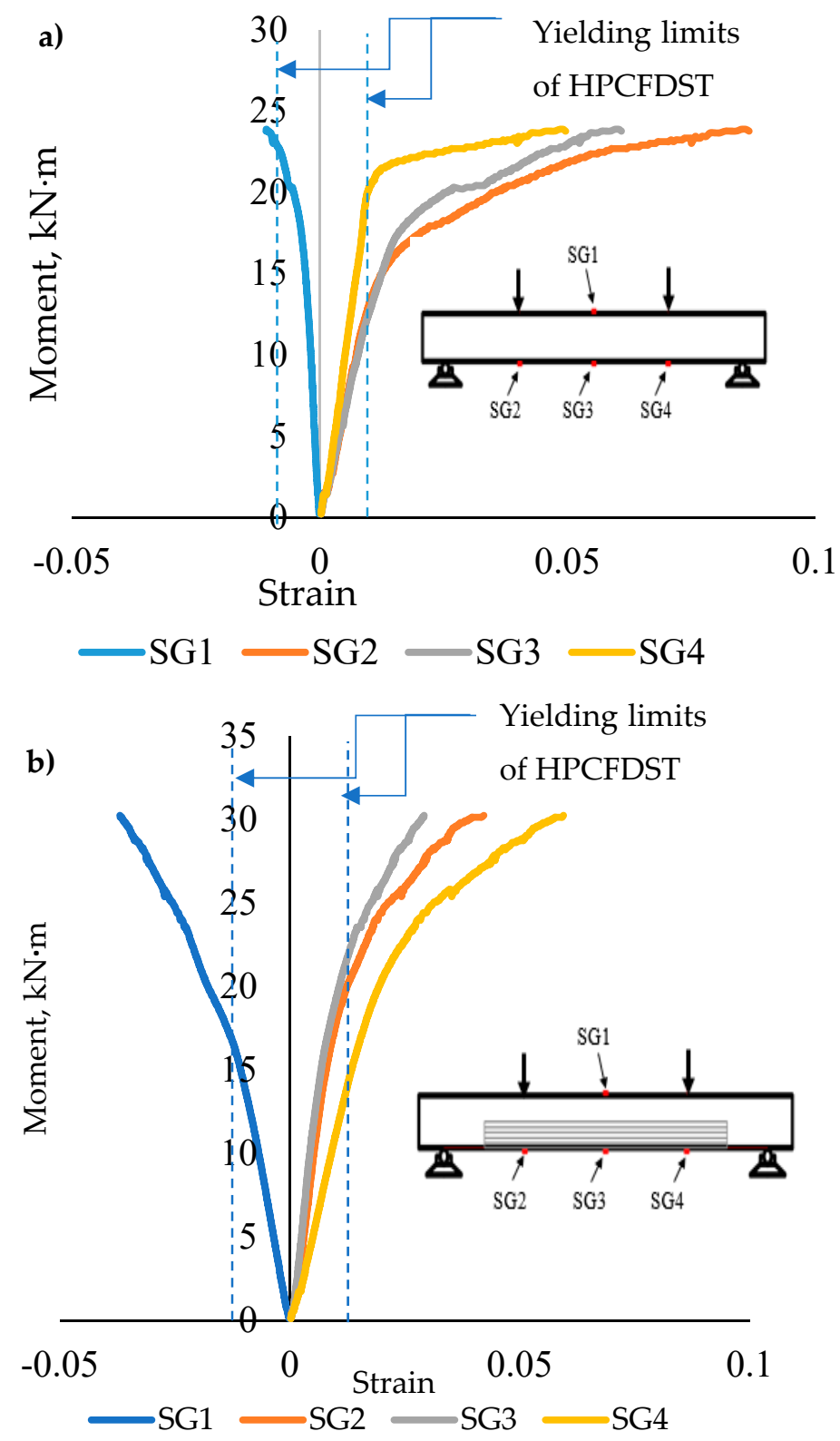

Figure 9. Relationship between moment and strain for (a) B-C and (b) B-P75-2L specimens.

\subsubsection{Energy Absorption}

The energy absorption capabilities of seven totally different specimens (B-P100-2L, B-F100-2L, B-F100-1L, B-P50-2L, B-P100-3L, and B-F100-3L) have been studied in comparison with the control beam (C-B). The energy absorption capability can be determined by calculating the area under the envelope (curve) of load against deflection at mid-span of all the tested specimens. The load-deformation curve for two selected specimens, control beam (B-C) and strengthened specimen (B-P100-2L), from which areas were evaluated, as shown in Figure 10a,b. Based on this and as shown in Figure 11, it can be expressed that the absorption of energy of the B-P100-2L and B-F100-2L specimens has shown the most increase, among all tested samples, from $7912.8 \mathrm{kN} \cdot \mathrm{mm}$, recorded for control beam, to 8076.31 and $8396.1 \mathrm{kN} \cdot \mathrm{mm}$, correspondingly. It is noteworthy, however, that the subject of the specimen to delamination and rupture primarily at the early loading stage can go a long way in affecting their performance. This has been the case for the B-P50-2L and B-F100-1L specimens. They have the lowest energy absorption capacity values of 5416.3 and $5431.14 \mathrm{kN} \cdot \mathrm{mm}$, respectively. Additionally, it can be seen that the B-P100-3L and B-F100-3L specimens have slightly lower energy absorption 
values than the control beam. This is due to the formation of three new layers of CFRP at the addition of high-performing fibers to the cementitious concrete, leading to an increase in stiffness and a corresponding decrease in ductility. As a conclusion, it is recommended to use two fully or partially wrapping layers for better efficiency of the beam.
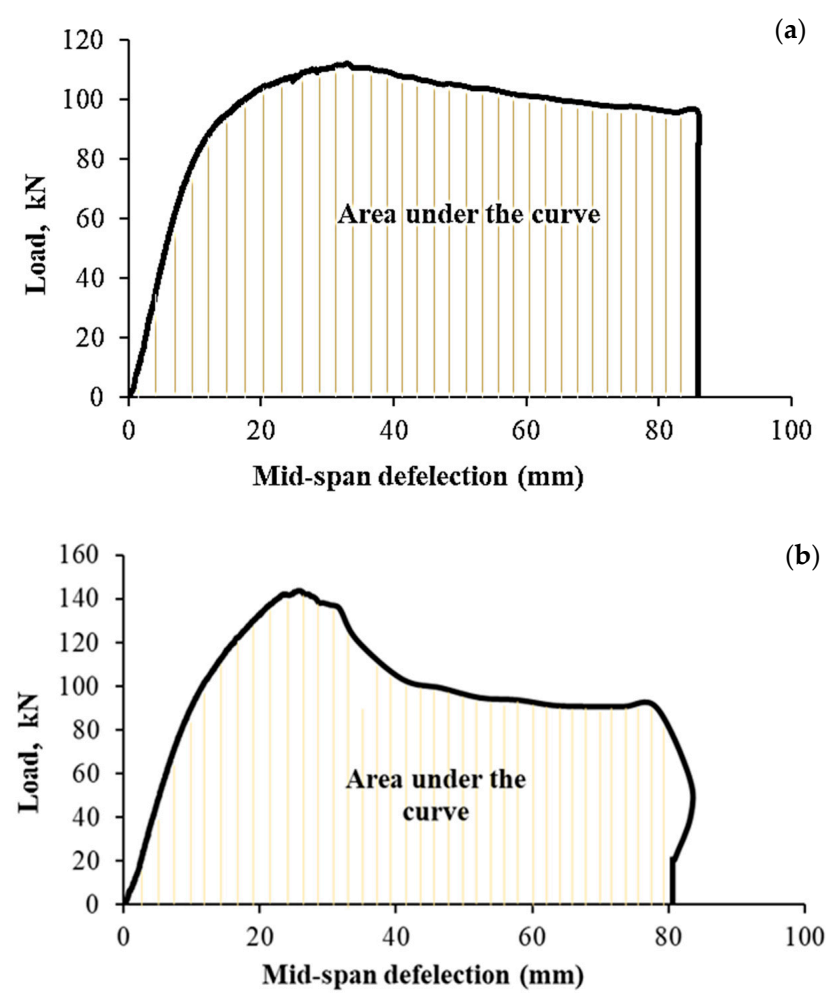

Figure 10. Characteristic load versus midspan deflection curves for assessing the energy absorption, (a) control specimen (B-C) and (b) strengthened specimen (B-P100-2L).

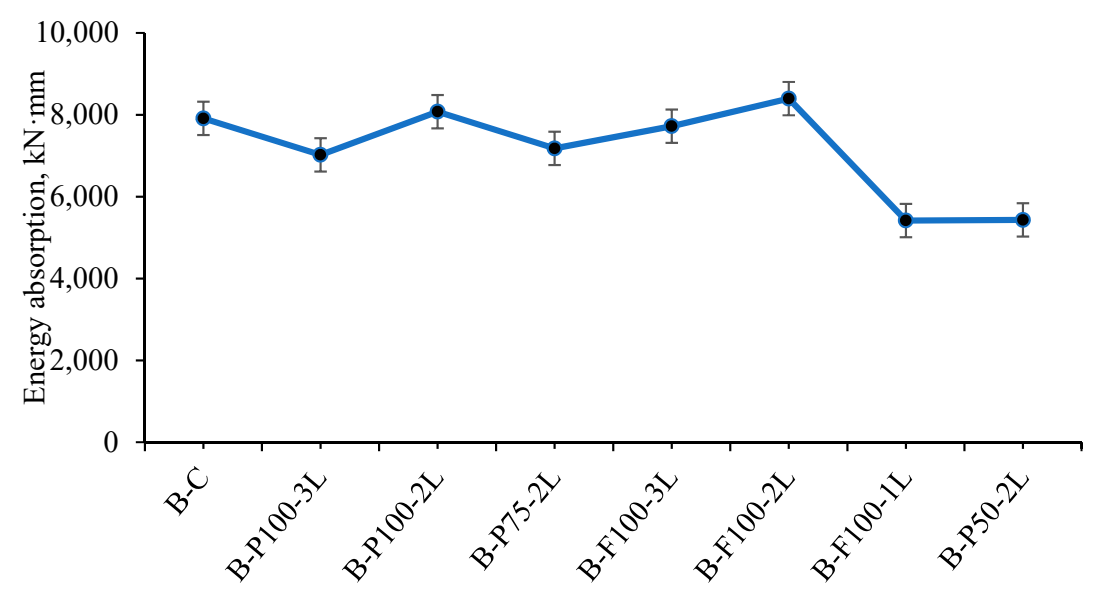

Figure 11. The value of energy absorption (EA) capacity for all specimens.

\subsubsection{Flexural Stiffness}

It is found that the impact of the addition of CFRP layers on the stiffness of the flexural of HFCFDST beams. Specimens B-C and B-P100-2L were chosen as typical examples for illustrating changes in flexural stiffness, determined from moment-curvature relation, as shown in Figure 12. The moment-curvature curve is applicable in the determination of the serviceability-level section flexural stiffness $\left(\mathrm{K}_{\mathrm{se}}\right)$ and the early section flexural stiffness $\left(\mathrm{K}_{\mathrm{ie}}\right)$ for every specimen. The $\mathrm{K}_{\mathrm{se}}$ and $\mathrm{K}_{\mathrm{ie}}$ are the secant stiffness; that are corresponding to the serviceability-level moment of $0.6 \mathrm{M}_{\mathrm{ue}}$ and 
equivalent to the moment of $0.2 \mathrm{M}_{\mathrm{ue}}$, respectively [30,35]. The two specimens initially exhibited elastic behavior before been pulled down gradually to an inelastic condition where eventual moment capacity $\left(\mathrm{M}_{\mathrm{ue}}\right)$ was attained. Table 5 presents the experimental results of $\mathrm{K}_{\mathrm{se}}$ and $\mathrm{Kie}$ resulting from the test done on HPCFDST samples. This can be further seen graphically in Figure 13. From the two results, we observed that both $\mathrm{K}_{\mathrm{se}}$ and $\mathrm{K}_{\mathrm{ie}}$ values augmented linearly with an increase in CFRP layers; the $\mathrm{K}_{\mathrm{se}}$ and $\mathrm{K}_{\mathrm{ie}}$ values for specimen B-C were elevated from the initial values of $491.8 \mathrm{kN} \cdot \mathrm{m}^{2}$ and 711.9 $\mathrm{kN} \cdot \mathrm{m}^{2}$, in the absence of CFRP sheets, to $699.7 \mathrm{kN} \cdot \mathrm{m}^{2}$ and $910.6 \mathrm{kN} \cdot \mathrm{m}^{2}$, when reinforced with 3 CFRP sheets. This indicates the increment in the stiffness quality of about $27.9 \%$ and $42.1 \%$ for $\mathrm{K}_{\mathrm{ie}}$ and $\mathrm{K}_{\mathrm{se}}$, respectively.
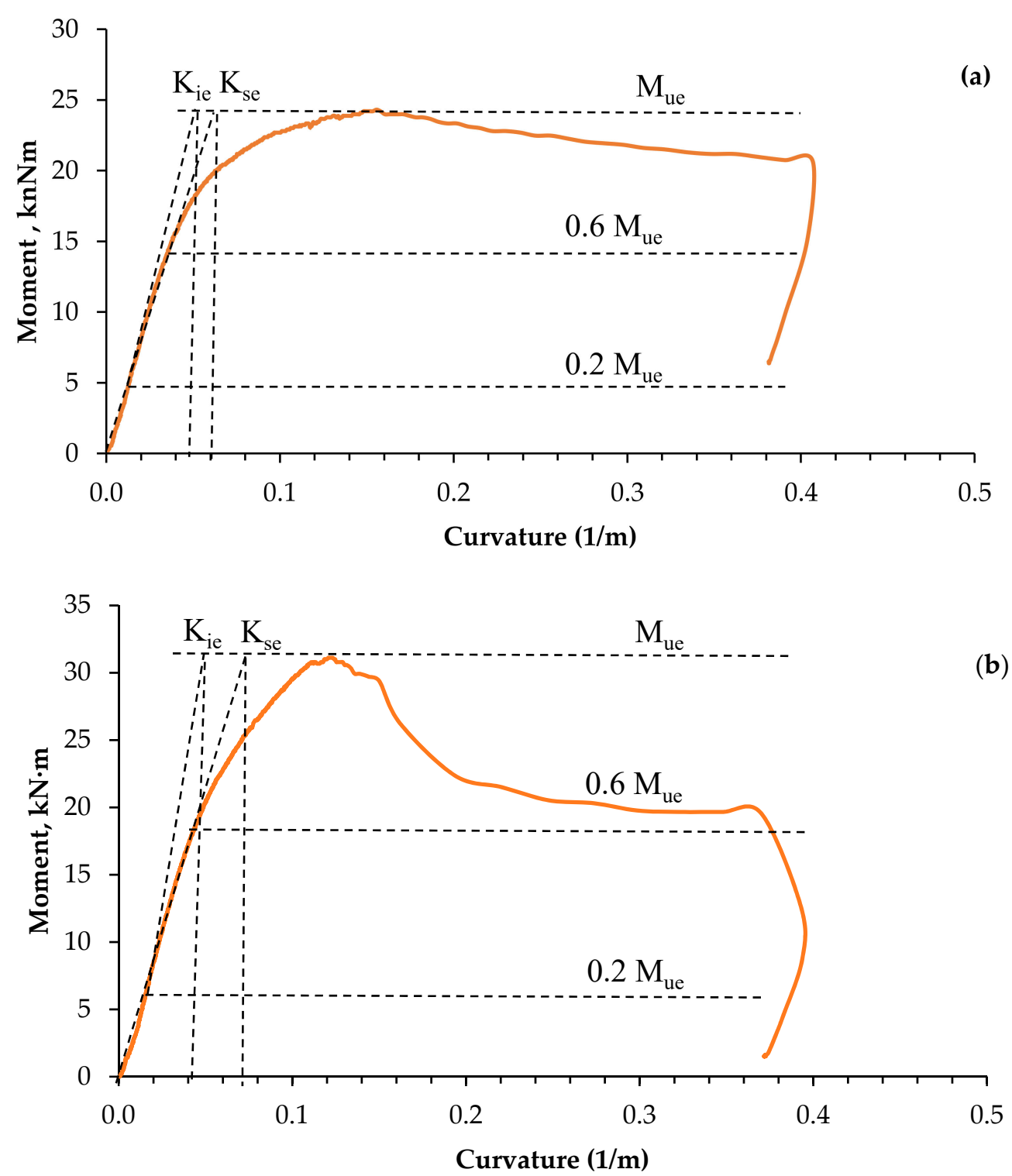

Figure 12. Typical relationships of bending moment-curvature: (a) reference specimen (B-C) and (b) integrated specimen (B-P100-2L). 


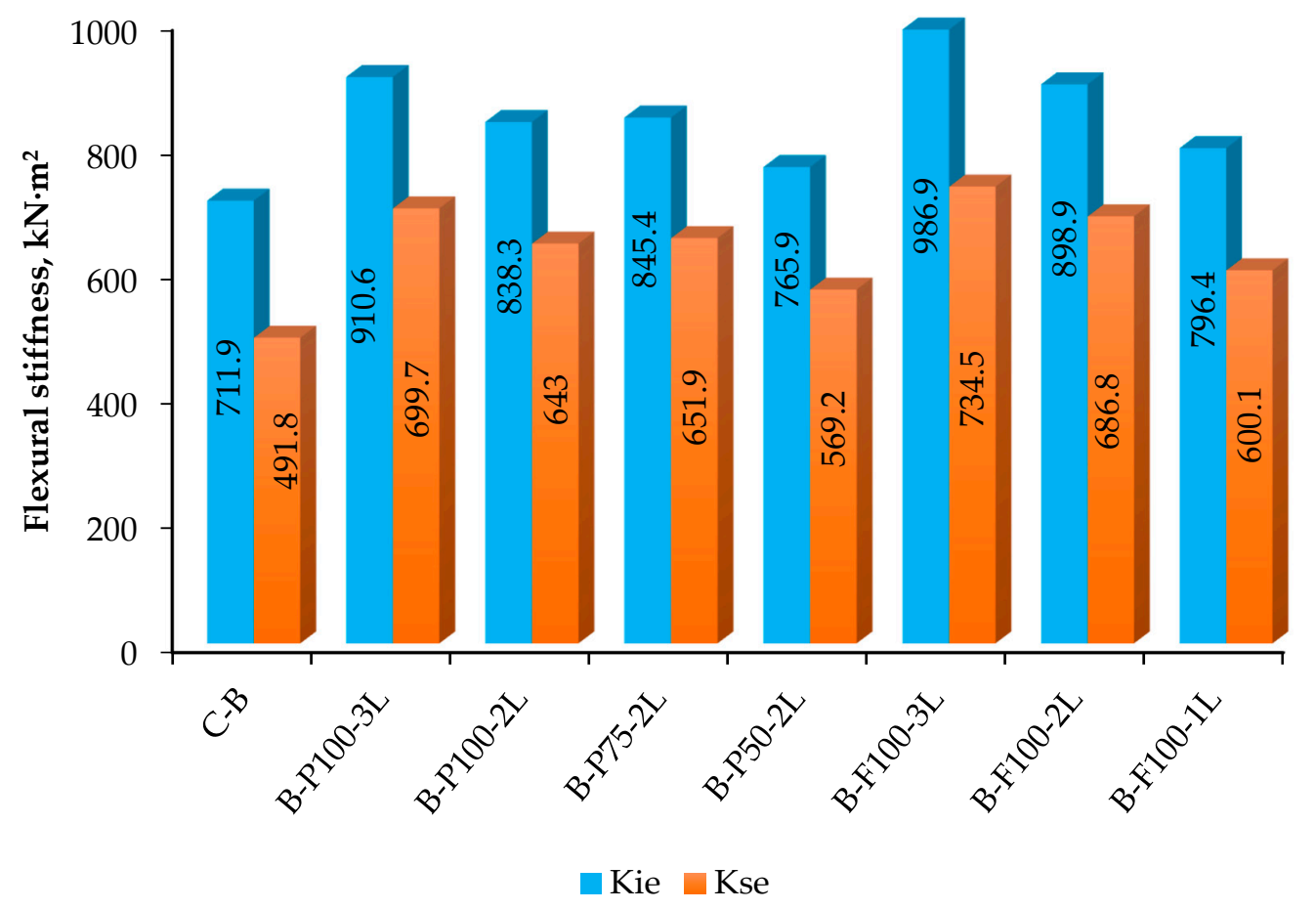

Figure 13. Flexural stiffness $\left(\mathrm{K}_{\mathrm{ie}}\right.$ and $\left.\mathrm{K}_{\mathrm{se}}\right)$ of HPCFDST specimens.

The actual flexural stiffness of CFST specimens has been estimated over a long time now through the conventional code methods; AIJ (1997) [36], EC4 (2004) [37], AISC (2010) [38], and BS5400 (1979) [39], and although, none of these methods have considered the role CFRP can play, the current experimental results indicated the enhancement efficiency that can be achieved in the flexural stiffness of HPCFDST beams by the addition of CFRP sheets. Therefore, in order to measure the effect of CFRP, this study recommends that the stiffness value of CFRP sheets should be obtained first and separate, and then added to the formulas of the conventional methods stated below:

1. $\quad$ AISC (2010)

$$
K_{p}=E_{s} \cdot I_{S}+C_{1} \cdot E_{c} \cdot I_{C}
$$

where, $C_{1}=0.6+0.2\left(A_{s} /\left(A_{s}+A_{\mathcal{C}}\right)\right) \leq 0.9, E_{C}=4733 \sqrt{f_{c}}$.

2. EC4 (2004)

$$
K_{p}=E_{s} \cdot I_{S}+0.6 \cdot E_{c} \cdot I_{c}
$$

where, $E_{c}=9500 \times\left(f_{c k}+8\right)^{\frac{1}{3}}, f_{C k}=0.67 f_{c u}$.

3. BS5400 (1979)

$$
K_{p}=E_{S} \cdot I_{S}+E_{c} \cdot I_{c}
$$

where, $E_{C}=450 \times f_{c u}$.

4. AIJ (1997)

$$
K_{p}=E_{s} \cdot I_{S}+0.2 E_{c} \cdot I_{c}
$$

where, $E_{c}=21000 \times \sqrt{f_{c} / 19.6}$.

Furthermore, the multi-CFRP sheets (the gluey sheets sandwiched were all taken as one sheet) have been represented with the CFRP patch technique as adopted by previous researchers [33]. The moment of inertia for every spot of the CFRP ( $\left.I_{C F R P . P a t c h}\right)$ was estimated from the geometry of the integrating system via the overall CFRP patch thickness $\left(t_{C F R P, P a t c h}\right)$. The thickness of every gluey layer attached to the strengthened specimens falls averagely between 0.8 and $1.0 \mathrm{~mm}$ after a series of measurements. 
The stiffness of CFRP $\left(K_{C F R P}\right)$, the modulus of elasticity, and the total thickness of for each CFRP patch were assessed as follows:

$$
\begin{gathered}
K_{c f r p}=E_{C F R \text {,Patch }} \times I_{C F R P . P a t c h} \\
t_{c f r p . p a t c h}=\left(n \times t_{c f r p, \text { sheet }}\right)+(n-1) \times t_{a d} \\
E_{c f r p . \text { patch }}=\left(n \times t_{c f r p, \text { sheet }} \times E_{c f r p . \text { sheet }}\right)+(n-1) \times t_{a d}
\end{gathered}
$$

The summation of the entire flexural stiffness of the integrated HPCFDST samples $\left(K_{t}\right)$, projected by means of each of the techniques, and the CFRP patch stiffness $\left(K_{C F R P}\right)$ was contrasted with the flexural stiffness at serviceability level and the original flexural stiffness $\left(K_{s e}\right.$ and $\left.K_{i e}\right)$ obtained from the experimental tests shown in Tables 6 and 7 , correspondingly. The standard deviation $\left(S_{d}\right)$, mean value $(\mathrm{MV})$, and variation coefficient (COV) of the ratio of the anticipated value-to-test value for the variable design techniques were all reported in these tables. The outcomes in Table 7 display obviously that the techniques of BS5400, AISC, and EC4 were moderated in approximating the original flexural stiffness $\left(K_{t} / K_{i e}\right)$ with MVs of around $0.606,0.404$, and 0.715 , respectively. Also, Its COV ranges from 5.072 to 6.940. The AIJ technique, meanwhile, was the best predictor as it attained an MV of 0.404 and a COV of about 5.072. This was due to the fact that the AIJ technique implemented a lesser reduction factor of 0.2 to compute the concrete flexural stiffness in contrast with the other aforementioned techniques. In Table 5, the COV and MV of the ratio of $K_{t} / K_{s e}$ for similar techniques were featured. It is clearly depicted in Table 5 that, at the serviceability level, the BS5400, EC4, and AISC techniques were highly moderated in the assessment of flexural stiffness, having, respectively, MVs of approximately 0.809, 0.540, and 0.956 and COVs from 8.340 to 10.063 . The AIJ technique also exhibited significant values, marginally greater than the experimental test results, reaching an average value of 0.540 and a CV of

\begin{tabular}{|c|c|c|c|c|c|c|c|c|c|c|c|}
\hline No. & $\begin{array}{l}\text { Labeling of } \\
\text { Specimens }\end{array}$ & $\begin{array}{l}\text { Kie } \\
\left(\mathbf{k N} \cdot \mathrm{m}^{2}\right)\end{array}$ & $\begin{array}{l}\mathrm{K}_{\mathrm{CRRP}} \\
\left(\mathrm{kN} \cdot \mathrm{m}^{2}\right)\end{array}$ & $\begin{array}{l}\operatorname{AISC}(2010) \mathrm{Kt} \\
\left(\mathrm{kN} \cdot \mathrm{m}^{2}\right)\end{array}$ & $\mathrm{Kt} / \mathrm{Kie}$ & $\begin{array}{l}\text { EC4 (2004) Kt } \\
\left(\mathrm{kN} \cdot \mathrm{m}^{2}\right)\end{array}$ & $\mathrm{Kt} / \mathrm{Kie}$ & $\begin{array}{c}\text { BSS400 (1979) } \\
\text { Kt }\left(\mathbf{k N} \cdot \mathrm{m}^{2}\right)\end{array}$ & $\mathrm{Kt} / \mathrm{Kie}$ & $\begin{array}{c}\text { AIJ (1997) Kt } \\
\left(\mathrm{kN} \cdot \mathrm{m}^{2}\right)\end{array}$ & $\mathrm{Kt} / \mathrm{Kie}$ \\
\hline 1 & B-C & 711.9 & 0 & 483.30 & 0.679 & 314.90 & 0.442 & 575.1 & 0.808 & 366.7 & 0.515 \\
\hline 2 & B-P100-3L & 910.6 & 34.75 & 518.05 & 0.569 & 349.65 & 0.384 & 609.8 & 0.670 & 401.5 & 0.441 \\
\hline 3 & B-P100-2L & 838.2 & 17.81 & 501.11 & 0.598 & 332.71 & 0.397 & 592.9 & 0.707 & 384.5 & 0.459 \\
\hline 4 & B-P75-2L & 845.4 & 17.81 & 501.11 & 0.593 & 332.71 & 0.394 & 592.9 & 0.701 & 384.5 & 0.455 \\
\hline 5 & B-P50-2L & 765.9 & 17.81 & 501.11 & 0.654 & 332.71 & 0.434 & 592.9 & 0.774 & 384.5 & 0.502 \\
\hline 6 & B-F100-3L & 986,9 & 69.50 & 552.8 & 0.560 & 384.40 & 0.390 & 644.6 & 0.653 & 436.2 & 0.442 \\
\hline 7 & B-F100-2L & 898.9 & 35.62 & 518.92 & 0.577 & 350.52 & 0.390 & 610.7 & 0.679 & 402.3 & 0.448 \\
\hline 8 & B-F100-1L & 796.4 & 6.07 & 489.37 & 0.614 & 320.97 & 0.403 & 581.2 & 0.730 & 372.8 & 0.468 \\
\hline Average & - & - & - & - & 0.606 & - & 0.404 & - & 0.715 & - & 0.466 \\
\hline $\mathrm{Sd}^{\circ}$ & - & - & - & - & 0.039 & - & 0.021 & - & 0.050 & - & 0.026 \\
\hline $\operatorname{COV}(\%)$ & - & - & - & - & 6.464 & - & 5.072 & - & 6.940 & - & 5.594 \\
\hline
\end{tabular}
8.340 .

Table 6. The comparative result among predicted total flexural stiffness $\left(K_{t}\right)$ and test results of $K_{\mathrm{ie}}$.

\begin{tabular}{|c|c|c|c|c|c|c|c|c|c|c|c|}
\hline No. & $\begin{array}{l}\text { Labeling of } \\
\text { Specimens }\end{array}$ & $\begin{array}{c}\text { Kse } \\
\left(\mathbf{k N} \cdot \mathrm{m}^{2}\right)\end{array}$ & $\begin{array}{l}\text { KCRRP } \\
\left(\mathbf{k N} \cdot \mathrm{m}^{2}\right)\end{array}$ & $\begin{array}{c}\text { AISC (2010) Kt } \\
\left(\mathrm{kN} \cdot \mathrm{m}^{2}\right)\end{array}$ & $\mathrm{Kt} / \mathrm{Kse}$ & $\begin{array}{c}\text { EC4 (2004) Kt } \\
\left(\mathrm{kN} \cdot \mathrm{m}^{2}\right)\end{array}$ & $\mathrm{Kt} / \mathrm{Kse}$ & $\begin{array}{c}\text { BSS400 (1979) } \\
\text { Kt }\left(\mathbf{k N} \cdot \mathrm{m}^{2}\right)\end{array}$ & $\mathrm{Kt} / \mathrm{Kse}$ & $\begin{array}{l}\mathrm{AIJ}(1997) \mathrm{Kt} \\
\left(\mathrm{kN} \cdot \mathrm{m}^{2}\right)\end{array}$ & $\mathrm{Kt} / \mathrm{Kse}$ \\
\hline 1 & B-C & 491.8 & 0.00 & 483.30 & 0.983 & 314.90 & 0.640 & 575.10 & 1.169 & 366.70 & 0.746 \\
\hline 2 & B-P100-3L & 699.7 & 34.75 & 518.05 & 0.740 & 349.65 & 0.500 & 609.85 & 0.872 & 401.45 & 0.574 \\
\hline 3 & B-P100-2L & 643.0 & 17.81 & 501.11 & 0.779 & 332.71 & 0.517 & 592.91 & 0.922 & 384.51 & 0.598 \\
\hline 4 & B-P75-2L & 651.9 & 17.81 & 501.11 & 0.769 & 332.71 & 0.510 & 592.91 & 0.910 & 384.51 & 0.590 \\
\hline 5 & B-P50-2L & 569.2 & 17.81 & 501.11 & 0.880 & 332.71 & 0.585 & 592.91 & 1.042 & 384.51 & 0.676 \\
\hline 6 & B-F100-3L & 734.5 & 69.50 & 552.8 & 0.753 & 384.4 & 0.523 & 644.6 & 0.878 & 436.2 & 0.594 \\
\hline 7 & B-F100-2L & 686.8 & 35.62 & 518.92 & 0.756 & 350.52 & 0.510 & 610.72 & 0.889 & 402.32 & 0.586 \\
\hline 8 & B-F100-1L & 600.1 & 6.07 & 489.37 & 0.815 & 320.97 & 0.535 & 581.17 & 0.968 & 372.77 & 0.621 \\
\hline Average & - & - & - & - & 0.809 & - & 0.540 & - & 0.956 & - & 0.623 \\
\hline $\mathrm{Sd}^{\circ}$ & - & - & - & - & 0.078 & - & 0.045 & - & 0.096 & - & 0.055 \\
\hline $\operatorname{COV}(\%)$ & - & - & - & - & 9.626 & - & 8.340 & - & 10.063 & - & 8.826 \\
\hline
\end{tabular}

Table 7. The comparative result among predicted total flexural stiffness $\left(K_{t}\right)$ and test results of $K_{s e}$.

\subsubsection{Failure Modes}

At the ultimate loading stage, all specimens were overloaded to obtain more understanding of the behavior of HPCFDST specimens when integrated with the CFRP sheet at the ultimate load stage. Generally, even beyond the ultimate failure limit of the tested specimens, the loading test was continued. The modes of failure of the HPCFDST specimens are presented in Table 5. No change was noticed in the shapes of HPCFDST beams at the time of testing until they attained their ultimate 
strength capacities. For all tested specimens, the outward buckling failure (local) that was at the top surface of the steel (close to points of loading), were monitored and recorded together with CFRP wrapped schemes as shown in Figure 14. For instance, Figure 15a,b indicates a control sample (B-C) and wrapped sample (B-F100-3L), respectively. The main difference amidst non-strengthened and strengthened samples was that the wrapped specimens attained a higher maximum load capacity when the CFRP sheets ruptured. It then returned to virtually the same level as the non-strengthened until the deflection value of the outward local failure is nearly identical.

Furthermore, for some selected samples, the curves illustrated the deflection behavior at various bending stages that are similar to the sine-curved shape, as displayed in Figure 16, while Figure 14 reflects the modes of failure of the samples. The pure-tension region first gave way to a small cracking sound in the CFRP (at the bottom center of the sample) when the wrapped samples got to about 85-90\% of the maximum ultimate capacity. Similarly, other patterns of failure were observed for all samples. For these specimens, once the ultimate tensile strength is achieved, a rupture from the central portion is observed in their CFRP as a result of the high bending stress. The specimen with $50 \%$ strength lengths suffered delamination at the ends of the CFRP before their maximum strength was reached. This failure was accorded to a large volume of flaking stress that happened all over the bonding surfaces between the steel and CFRP layers as a result of the considerable bending stress at the peeling point which decreases gradually towards the end supports, discovering that delamination failure took place because the CFRP layers with 50\% wrapped lengths were placed inside the zones where flaking stress is high as shown in Figure 17. However, the flaking stress might be overridden by the strength of bonding between the steel tubes and the CFRP layers for 75\% wrapped lengths, hence, avoiding the occurrence of the failure mode of delamination or debonding.

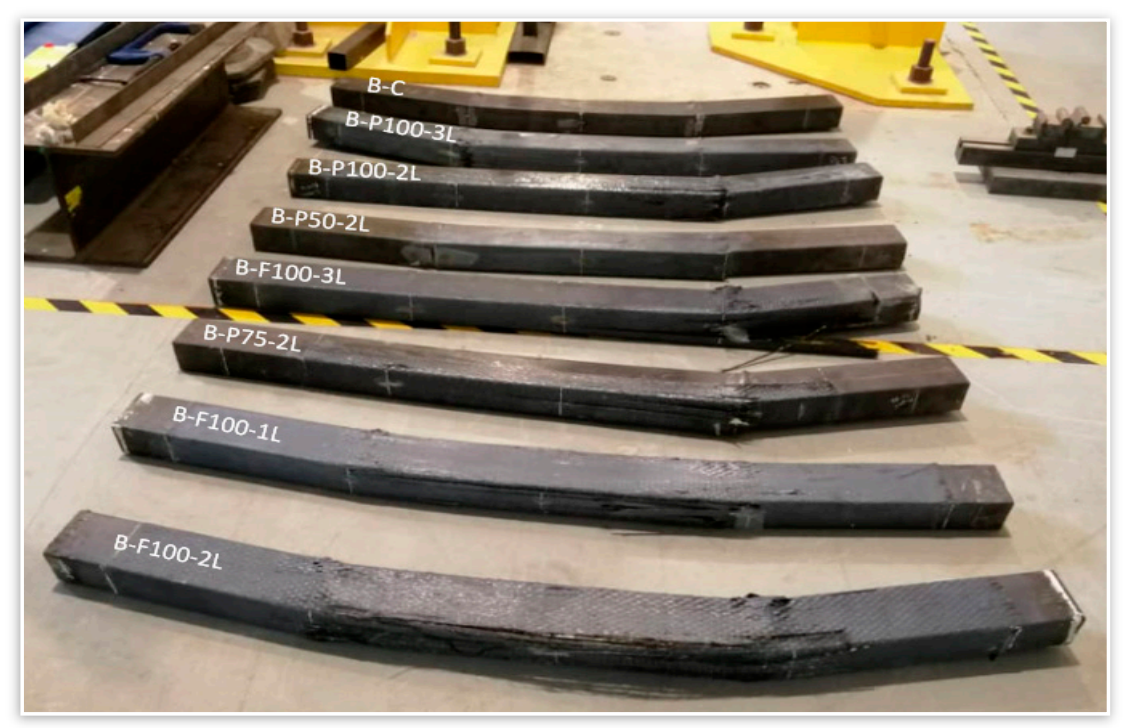

Figure 14. Failure modes of all tested HPCFDST samples. 

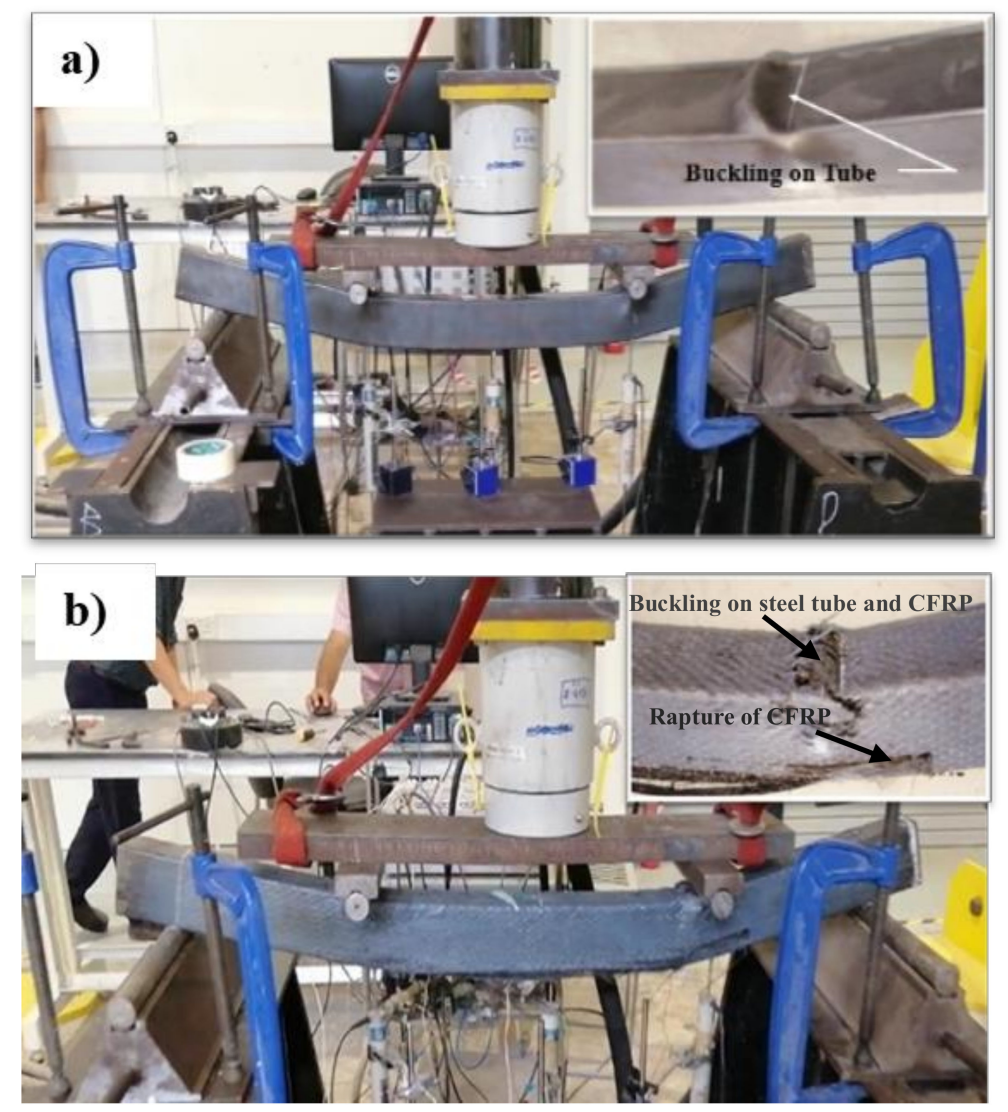

Figure 15. Buckling failure characteristic at the top surface of steel tubes (at the final loading phase); (a) B-C and (b) B-P100-3L.

It is concluded that the failure mode of (B-P75-2L, B-F100-2L, B-P100-3L, and B-P100-2L) beams is a one-sided failure. The reason for the single failure mode is associated with the incomplete compaction of the concrete within the beam's specimens, thereby generating voids or opening within the beams. Similarly, there is the possibility of fiber agglomeration at one side of the beams that can make it stronger from the other sides. A steady CFRP rupture failure was noticed from the tension zone of beams under the point load in fully strengthening specimens B-F100-2L, B-100F-1L, and B-F100-3L. The no-slip failure between the steel tube and concrete core was seen in all specimens, as both ends of each specimen were visually checked and inspected during the tests. 


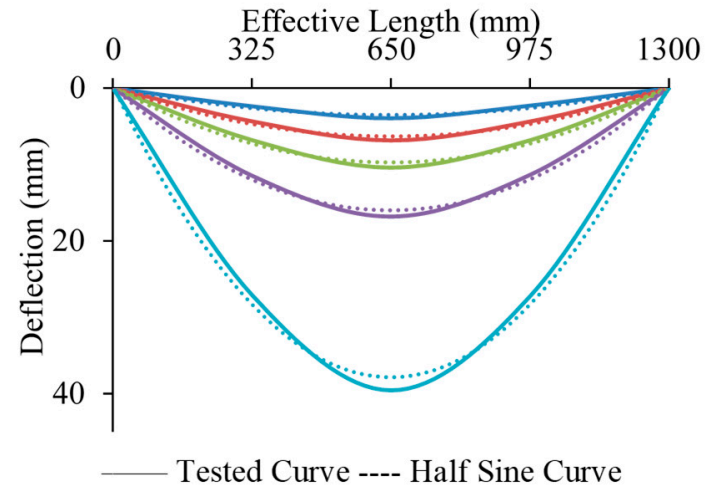

(a)

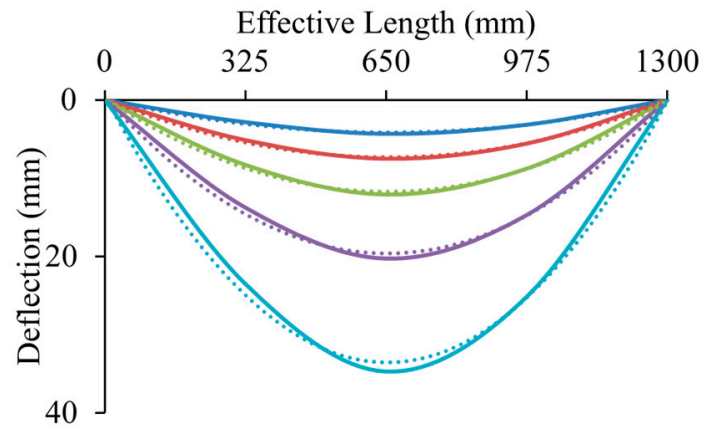

(c)

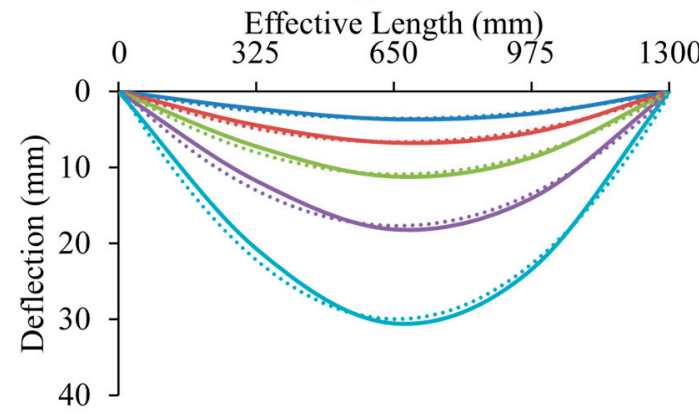

Tested Curve ----Half Sine Curve

(e)

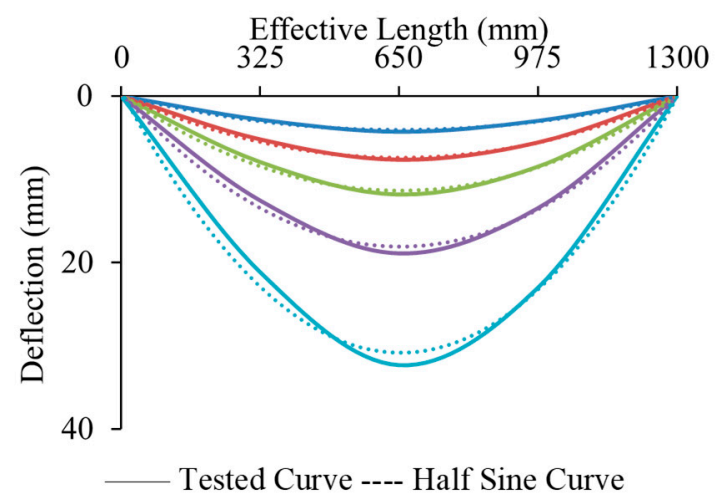

(b)

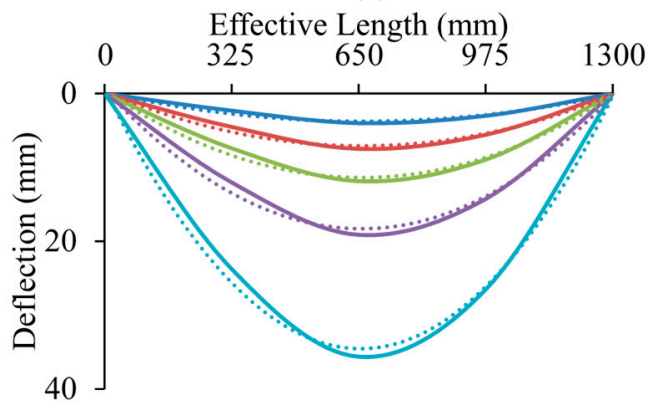

(d)

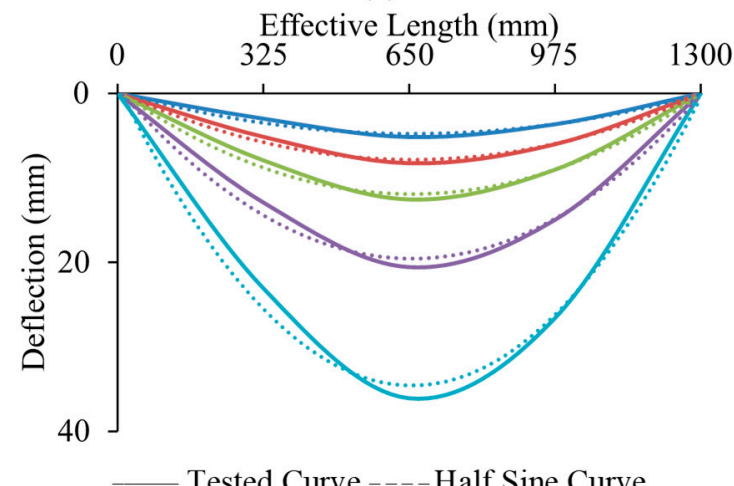

(f)

Figure 16. Deformation shapes in various loading phases: (a) B-C; (b) B-P100-3L; (c) B-P100-2L; (d) B-P75-2L; (e) B-F100-2L; (f) B-F100-2L.

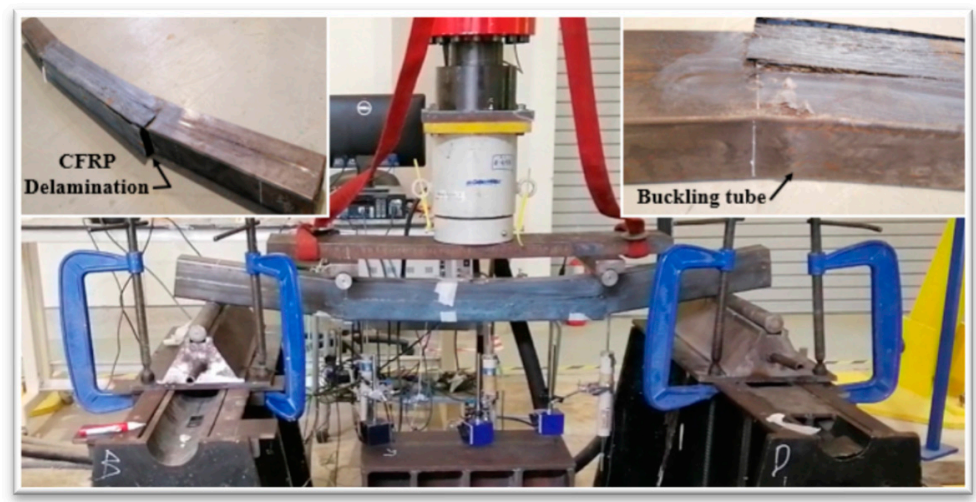

Figure 17. CFRP failure mode of (B-P50-2L) specimen. 


\subsubsection{Summary of Study}

This study focused on investigating the flexural performance of double-skinned steel beams filled with fiber-reinforced concrete (FRC). The significance of concrete-filled steel members was to design the very long flexural member with small cross-sectional dimensions. Through composite action, the cross-sectional load-carrying capacity could be enhanced. Most of the available research studies were focused on single and fully filled with concrete. Whereas, in the study, the double skin further enhanced the structural capacity and also reduced the amount of concrete to be filled. The FRC used was high strength and high performance in a nature that contributed better compatibility in stress transfer between steel sections and infilled concrete.

\section{Conclusions}

This study presents the flexural behavior of double-skin steel tube beams filled with fiber-reinforced cementitious composite and strengthened with CFRP sheets. The conclusion can be drawn as follows:

- $\quad$ The investigated of moment-carrying capacity results represent that the upsurge in the moment capacity of the strengthening HPCFDST beams was as a result of an increment in the number of sheets of the CFRP. For instance, the $\mathrm{M}_{\mathrm{ue}}$ value of the B-P100-2 beam using two layers and B-P100-3L beams using three layers were raised to $+28.5 \%$ and $32.6 \%$, respectively, compared to the control specimen. Moreover, the moment capacity of the B-P75-2L was raised to $+25 \%$ more than the control samples' average capacity because of using two layers of the CFRP along 75\% of its effective length which was extremely close to the result obtained for the B-F100-2L specimen (+ $26 \%$ ) as in either specimen. Thus, it is better to use partial wrapping instead of full strengthening of CFRP for the purpose of cost-effectiveness;

- The moment-curvature responses of the HPCFDST beam strengthened with CFRP displayed elastic performance at the early loading stages and then plastic behavior with stiffness reducing progressively as exhibited by all specimens till the maximum moment capacity was achieved. The behavior of strengthened specimens after the CFRP rupture developed and became similar to the reference specimens until the ultimate strength capacity.

- Energy absorption can be concluded that the energy absorptivity of the specimens B-P100-2L and B-F100-2L showed the most increase, among all tested samples, from $7912.8 \mathrm{kN} \cdot \mathrm{mm}$, recorded for control beam, to 8076.31 and $8396.1 \mathrm{kN} \cdot \mathrm{mm}$, respectively. However, the remaining specimens had lower energy absorption values than the control beam. This was due to the formation of new three layers of CFRP at the addition of high-performing fibers to the cementitious concrete, leading to an increase in stiffness and a corresponding decrease in ductility. As a conclusion, it is recommended to use fully or partially wrapping of two layers for better efficiency of the beam.

- The flexural stiffness values increased linearly with an increase in CFRP layers; the Kie and Kse values for specimens B-C were elevated from the initial 711.9 and $491.8 \mathrm{kN} \cdot \mathrm{m}^{2}$, in the absence of CFRP layers, to $910.6 \mathrm{kN} \cdot \mathrm{m}^{2}$ and $699.7 \mathrm{kN} \cdot \mathrm{m}^{2}$, when integrated with 3 CFRP sheets.

- The failure modes For all tested specimens displayed the outward buckling failure (local) that was at the top surface of the steel (close to points of loading). Similar patterns of failure were recorded for all samples. It is seen that when the ultimate tensile strength is achieved, a rupture from the central portion is observed in their CFRP as a result of the high bending stress. However, the specimen with 50\% strength lengths (B-P50-2L) suffered delamination at the ends of the CFRP before their maximum strength was reached. Delamination failure took place because the CFRP layers with half wrapped extents were placed within the zones where flaking stress is high.

Author Contributions: Conceptualization, A.A.-N., E.N., N.S. and A.A.-F.; Methodology, A.A.-N. and N.S.; Validation, A.A.-N.; Formal Analysis, A.A.-N., A.A.-F. and W.A.-N.; Investigation, A.A.-N.; Resources, E.N., B.S.M., and A.S.; Data Curation, A.A.-N. and A.A.-F.; Writing-Original Draft Preparation, A.A.-N., A.A.-F. and N.S.; Writing-Review and Editing, A.A.-N., A.A.-F. and Y.H.M.A.; Visualization, A.A.-N., N.S. and E.N.; Supervision, 
E.N., N.S. and B.S.M.; Project Administration, E.N. and N.S.; Funding Acquisition, E.N. and A.S. All authors have read and agreed to the published version of the manuscript.

Funding: This research was supported by the Fundamental Research Grant Scheme of Malaysia [grant number FRGS/1/2018/TK01/UTP/02/9].

Acknowledgments: The authors wish to thank Universiti Teknologi PETRONAS (UTP) and Universiti Tenaga Nasional (UNITEN) for providing monetary support and an intellectual platform during this research.

Conflicts of Interest: The authors declare no conflict of interest.

\section{Notations}

\begin{tabular}{|c|c|c|c|}
\hline Symbol & Description & Symbol & Description \\
\hline $\mathrm{A}_{\mathrm{SO}}$ & Outer steel tube area $\left(\mathrm{mm}^{2}\right)$ & $\mathrm{f}_{\mathrm{ck}}$ & Characteristic of concrete strength (MPa) \\
\hline $\mathrm{A}_{\mathrm{SI}}$ & Inner steel tube area $\left(\mathrm{mm}^{2}\right)$ & $\mathrm{f}_{\mathrm{y}}$ & Yielding strength of steel tube (MPa) \\
\hline $\mathrm{A}_{\mathrm{HPC}}$ & Area of high-performance concrete $\left(\mathrm{mm}^{2}\right)$ & $f_{u}$ & Ultimate strength of steel (MPa) \\
\hline $\mathrm{B}_{\mathrm{S}}$ & Width of outer steel tube (mm) & HPCFDST & $\begin{array}{l}\text { High-performance fiber-reinforced cementitious } \\
\text { filled-double skin steel tube }\end{array}$ \\
\hline $\mathrm{D}_{\mathrm{S}}$ & Depth of outer steel tube (mm) & CFRP & Carbon fiber-reinforced polymer \\
\hline $\mathrm{b}_{\mathrm{S}}$ & Width of inner steel tube (mm) & $\mathrm{F}$ & Full wrapping sheet \\
\hline $\mathrm{d}_{\mathrm{S}}$ & Depth of inner steel tube (mm) & $\mathrm{P}$ & Partial wrapping sheet \\
\hline $\mathrm{B}_{\mathrm{C}}$ & Width of outer concrete (mm) & $\mathrm{I}_{\mathrm{SI}}$ & Moment inertia of inner steel tube $\left(\mathrm{mm}^{4}\right)$ \\
\hline $\mathrm{D}_{\mathrm{C}}$ & Depth of outer concrete (mm) & $\mathrm{I}_{\mathrm{SO}}$ & Moment inertia of outer steel tube $\left(\mathrm{mm}^{4}\right)$ \\
\hline bc & Width of inner concrete (mm) & $\mathrm{I}_{\mathrm{S}}$ & $\begin{array}{l}\text { Moment inertia of steel cross-section (inner and } \\
\text { outer) }\left(\mathrm{mm}^{4}\right)\end{array}$ \\
\hline $\mathrm{d}_{\mathrm{C}}$ & Depth of inner concrete (mm) & $\mathrm{I}_{\mathrm{C}}$ & $\begin{array}{l}\text { Moment inertia of core HP concrete of cross-section } \\
\left(\mathrm{mm}^{4}\right)\end{array}$ \\
\hline EA & Energy adsorption $(\mathrm{kN} \cdot \mathrm{mm})$ & $\mathrm{L}$ & CFRP layers attached on CFDST \\
\hline $\mathrm{EC}$ & Modulus elasticity of concrete (GPa) & $\mathrm{t}$ & The thickness of the steel tube (mm) \\
\hline $\mathrm{E}_{\mathrm{SI}}$ & Modulus elasticity of inner steel tube (GPa) & $\mathrm{L}_{\mathrm{e}}$ & Effective length (support to support) (mm) \\
\hline $\mathrm{ES}_{\mathrm{O}}$ & Modulus elasticity of outer steel tube (GPa) & $\begin{array}{l}\mathrm{t}_{\text {CFRP, }} \\
\text { Scheme }\end{array}$ & Thickness of CFRP scheme (mm) \\
\hline $\mathrm{E}_{\mathrm{ST}}$ & Total modulus elasticity of steel tube (GPa) & $\mathrm{Kp}$ & Flexural stiffness of HPCFDST Beam $\left(\mathrm{kN} \cdot \mathrm{m}^{2}\right)$ \\
\hline $\begin{array}{l}E_{C F R P}, \\
\text { Scheme }\end{array}$ & CFRP scheme modulus of elasticity (GPa) & $\mathrm{K}_{\mathrm{CFRP}}$ & The flexural stiffness of CFRP sheet $\left(\mathrm{kN} \cdot \mathrm{m}^{2}\right)$ \\
\hline $\mathrm{E}_{\mathrm{adm}}$ & $\begin{array}{l}\text { Modulus elasticity of adhesive martial } \\
\text { (GPa) }\end{array}$ & $\mathrm{K}_{\mathrm{t}}$ & $\begin{array}{l}\text { Total flexural stiffness of specimen (concrete, steel, } \\
\text { and CFRP) }\left(\mathrm{kN} \cdot \mathrm{m}^{2}\right)\end{array}$ \\
\hline $\mathrm{f}_{\mathrm{cu}}$ & Compressive strength of HP concrete cube & LIR & Load improvement ratio \\
\hline M & Bending moment $(\mathrm{kN} \cdot \mathrm{m})$ & $\mathrm{K}_{\mathrm{ie}}$ & $\begin{array}{l}\text { Initial flexural stiffness of composite member } \\
\left(\mathrm{kN} \cdot \mathrm{m}^{2}\right)\end{array}$ \\
\hline $\mathrm{M}_{\mathrm{ue}}$ & Ultimate moment bending capacity & $\mathrm{K}_{\mathrm{se}}$ & $\begin{array}{l}\text { Serviceability-level flexural stiffness of composite } \\
\text { member }\left(\mathrm{kN} \cdot \mathrm{m}^{2}\right)\end{array}$ \\
\hline B & Beam & $\varphi \mathrm{COV}$ & Curvature $(1 / \mathrm{m})$ Coefficient of variation \\
\hline C & Control & $\mathrm{S}_{\mathrm{d}} \mathrm{MV}$ & Standard deviation Mean value or average \\
\hline
\end{tabular}

\section{References}

1. Moon, J.; Roeder, C.W.; Lehman, D.E.; Lee, H.-E. Analytical modeling of bending of circular concrete-filled steel tubes. Eng. Struct. 2012, 42, 349-361. [CrossRef]

2. Alostaz, Y.M.; Schneider, S.P. Analytical behavior of connections to concrete-filled steel tubes. J. Constr. Steel Res. 1996, 40, 95-127. [CrossRef]

3. Han, L.-H.; Li, W.; Bjorhovde, R. Developments and advanced applications of concrete-filled steel tubular (CFST) structures: Members. J. Constr. Steel Res. 2014, 100, 211-228. [CrossRef]

4. Susantha, K.; Ge, H.; Usami, T. Uniaxial stress-strain relationship of concrete confined by various shaped steel tubes. Eng. Struct. 2001, 23, 1331-1347. [CrossRef]

5. Hatzigeorgiou, G.D. Numerical model for the behavior and capacity of circular CFT columns, Part II: Verification and extension. Eng. Struct. 2008, 30, 1579-1589. [CrossRef]

6. Hatzigeorgiou, G.D. Numerical model for the behavior and capacity of circular CFT columns, Part I: Theory. Eng. Struct. 2008, 30, 1573-1578. [CrossRef]

7. Nikbakht, E.; Al-Fakih, A.; Hui, C.C.; Jake, L.Y.; Mahzabin, M.S. An experimental investigation on the shear and flexural behavior of steel reinforced HPSCC beams. Structures 2019, 19, 286-295. [CrossRef] 
8. El-Zeadani, M.; MR, R.S.; Amran, Y.M.; Hejazi, F.; Jaafar, M.; Alyousef, R.; Alabduljabbar, H. Analytical mechanics solution for measuring the deflection of strengthened RC beams using FRP plates. Case Stud. Constr. Mater. 2019, 11, e00272. [CrossRef]

9. Oehlers, D.J.; Visintin, P.; Lucas, W. Flexural Strength and Ductility of FRP-Plated RC Beams: Fundamental Mechanics Incorporating Local and Global IC Debonding. J. Compos. Constr. 2016, 20, 04015046. [CrossRef]

10. El-Zeadani, M.; Saifulnaz, M.R.R.; Mugahed Amran, Y.H.; Hejazi, F.; Jaafar, M.S.; Alyousef, R.; Alabduljabbar, H. Flexural strength of FRP plated RC beams using a partial-interaction displacement-based approach. Structures 2019, 22, 405-420. [CrossRef]

11. Nakamura, S.; Momiyama, Y.; Hosaka, T.; Homma, K. New technologies of steel/concrete composite bridges. J. Constr. Steel Res. 2002, 58, 99-130. [CrossRef]

12. Amran, Y.M.; Alyousef, R.; Rashid, R.S.; Alabduljabbar, H.; Hung, C.-C. Properties and Applications of FRP in Strengthening RC Structures: A review. Structures 2018, 16, 208-238. [CrossRef]

13. Siddika, A.; Al Mamun, M.A.; Alyousef, R.; Amran, Y.M. Strengthening of reinforced concrete beams by using fiber-reinforced polymer composites: A review. J. Build. Eng. 2019, 25, 100798. [CrossRef]

14. El-Zeadani, M.; Saifulnaz, M.R.; Hejazi, F.; Amran, Y.M.; Jaafar, M.; Alyousef, R.; Alrshoudi, F. Mechanics-based approach for predicting the short-term deflection of CFRP plated RC beams. Compos. Struct. 2019, 225, 111169. [CrossRef]

15. Zhao, X.-L.; Zhang, L. State-of-the-art review on FRP strengthened steel structures. Eng. Struct. 2007, 29, 1808-1823. [CrossRef]

16. Elchalakani, M.; Zhao, X.L.; Grzebieta, R.H. Concrete-filled circular steel tubes subjected to pure bending. J. Constr. Steel Res. 2001, 57, 1141-1168. [CrossRef]

17. Deng, Y.; Tuan, C.Y.; Xiao, Y. Flexural Behavior of Concrete-Filled Circular Steel Tubes under High-Strain Rate Impact Loading. J. Struct. Eng. 2012, 138, 449-456. [CrossRef]

18. Deng, Y.; Tuan, C.Y.; Zhou, Q.; Xiao, Y. Flexural strength analysis of non-post-tensioned and post-tensioned concrete-filled circular steel tubes. J. Constr. Steel Res. 2011, 67, 192-202. [CrossRef]

19. Elchalakani, M.; Zhao, X.-L.; Grzebieta, R. Tests on concrete filled double-skin (CHS outer and SHS inner) composite short columns under axial compression. Thin-Walled Struct. 2002, 40, 415-441. [CrossRef]

20. Tao, Z.; Han, L.-H. Behaviour of concrete-filled double skin rectangular steel tubular beam-columns. J. Constr. Steel Res. 2006, 62, 631-646. [CrossRef]

21. Yu, T.; Wong, Y.; Teng, J.; Dong, S.; Lam, E. Flexural behavior of hybrid FRP-concrete-steel double-skin tubular members. J. Compos. Constr. 2006, 10, 443-452. [CrossRef]

22. Uenaka, K.; Kitoh, H. Mechanical behavior of concrete filled double skin tubular circular deep beams. Thin-Walled Struct. 2011, 49, 256-263. [CrossRef]

23. Idris, Y.; Ozbakkaloglu, T. Flexural Behavior of Hybrid Double-Skin-Tubular Beams. Adv. Mat. Res. 2014, 838, 525-529. [CrossRef]

24. Jiashu, J.B.H.Z.C.; Wenjie, Z. An experimental study on the behavior of lightweight aggregate concrete filled circular steel tubes under pure bending load. China Civ. Eng. J. 2007, 8, 35-40.

25. Han, L.-H. Flexural behaviour of concrete-filled steel tubes. J. Constr. Steel Res. 2004, 60, 313-337. [CrossRef]

26. Han, L.-H.; Zhao, X.-L.; Tao, Z. Tests and mechanics model for concrete-filled SHS stub columns, columns and beam-columns. Steel Compos. Struct. 2001, 1, 51-74. [CrossRef]

27. Han, L.-H.; Yao, G.-H.; Tao, Z. Performance of concrete-filled thin-walled steel tubes under pure torsion. Thin-Walled Struct. 2007, 45, 24-36. [CrossRef]

28. Lye, H.L.; Mohammed, B.S.; Liew, M.S.; Wahab, M.M.A.; Al-Fakih, A. Bond behaviour of CFRP-strengthened ECC using Response Surface Methodology (RSM). Case Stud. Constr. Mater. 2020, 12, e00327. [CrossRef]

29. Roeder, C.W.; Lehman, D.E.; Bishop, E. Strength and stiffness of circular concrete-filled tubes. J. Struct. Eng. 2010, 136, 1545-1553. [CrossRef]

30. Wang, Q.; Shao, Y. Flexural performance of circular concrete filled CFRP-steel tubes. Adv. Steel Constr. 2015, 11, 127-149.

31. Nikbakht, E.; Shuhadah, N.I.; Ramanathan, A.L.G.; Shukanthi, A.P.S.; Bakar, N.A. Structural Behaviour of Strengthened High-Performance Concrete-Filled Double Skin Steel Tube Beams. In Proceedings of the ICACE 2019, Kuala Lumpur, Malaysia, 26-27 June 2019. 
32. Md Zin, N.; Al-Fakih, A.; Nikbakht, E.; Teo, W.; Anwar Gad, M. Influence of Secondary Reinforcement on Behaviour of Corbels with Various Types of High-Performance Fiber-Reinforced Cementitious Composites. Materials 2019, 12, 4159. [CrossRef] [PubMed]

33. Al Zand, A.W.; Badaruzzaman, W.H.W.; Mutalib, A.A.; Hilo, S.J. The enhanced performance of CFST beams using different strengthening schemes involving unidirectional CFRP sheets: An experimental study. Eng. Struct. 2016, 128, 184-198. [CrossRef]

34. ASTMC39. Standard Test Method for Compressive Strength of Cylindrical Concrete Specimens; ASTM International: West Conshohocken, PA, USA, 2018.

35. Wang, Q.-L.; Li, J.; Shao, Y.-B.; Zhao, W.-J. Flexural performances of square concrete filled CFRP-steel tubes (S-CF-CFRP-ST). Adv. Struct. Eng. 2015, 18, 1319-1344. [CrossRef]

36. AIJ. Architectural Institute of Japan (AIJ). Recommendations for Design and Construction of Concrete Filled Steel Tubular Structures; Architectural Institute of Tokyo: Tokyo, Japan, 1997.

37. EN 1994-1-1. Design of Composite Steel and Concrete Structures-Part 1-1: General Rules—Structural Fire Design; European Committee for Standardization: Brussels, Belgium, 2004.

38. AISC. Specification for Structural Steel Buildings; AISC: Chicago, IL, USA, 2010; Volume ANSI/AISC 360-10.

39. BS5400-5; Murali, B. Steel, Concrete and Composite Bridges; British Standard Institute: London, UK, 1979.

(C) 2020 by the authors. Licensee MDPI, Basel, Switzerland. This article is an open access article distributed under the terms and conditions of the Creative Commons Attribution (CC BY) license (http://creativecommons.org/licenses/by/4.0/). 